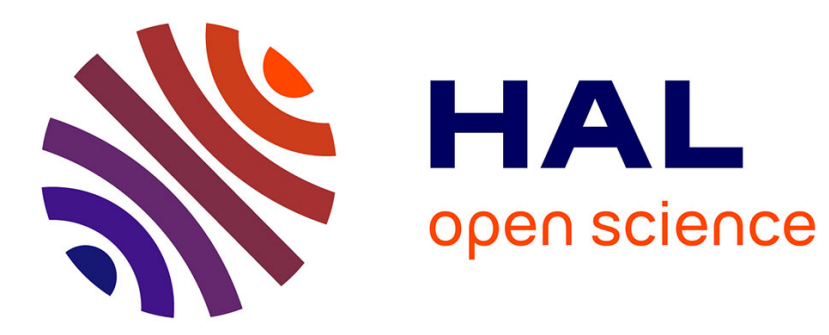

\title{
Managing Infrastructural and Service Demands in New Economic Spaces: The New Territorial Politics of Collective Provision
}

\author{
Andrew Jonas, Aidan While, David Gibbs
}

\section{To cite this version:}

Andrew Jonas, Aidan While, David Gibbs. Managing Infrastructural and Service Demands in New Economic Spaces: The New Territorial Politics of Collective Provision. Regional Studies, 2010, 44 (02), pp.183-200. 10.1080/00343400802662666 . hal-00566757

\section{HAL Id: hal-00566757 https://hal.science/hal-00566757}

Submitted on 17 Feb 2011

HAL is a multi-disciplinary open access archive for the deposit and dissemination of scientific research documents, whether they are published or not. The documents may come from teaching and research institutions in France or abroad, or from public or private research centers.
L'archive ouverte pluridisciplinaire HAL, est destinée au dépôt et à la diffusion de documents scientifiques de niveau recherche, publiés ou non, émanant des établissements d'enseignement et de recherche français ou étrangers, des laboratoires publics ou privés. 


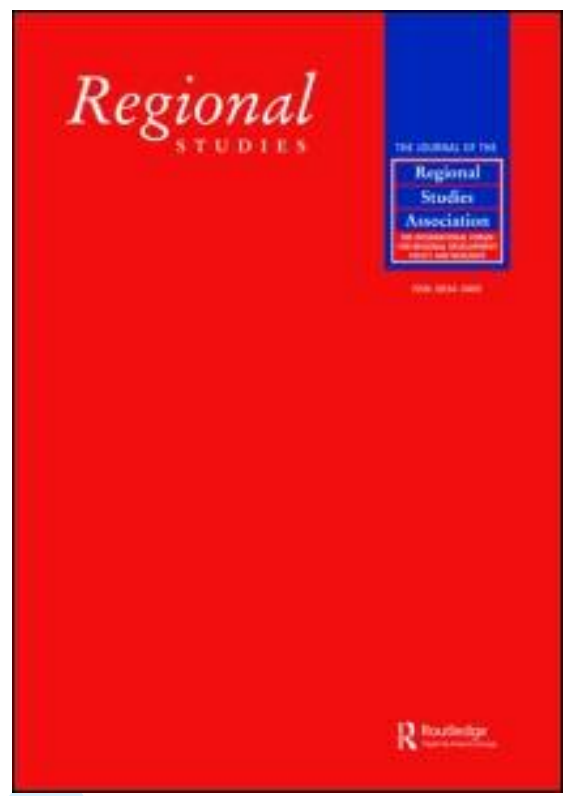

Managing Infrastructural and Service Demands in New Economic Spaces: The New Territorial Politics of Collective Provision

\begin{tabular}{|r|l|}
\hline Journal: & Regional Studies \\
\hline Manuscript ID: & CRES-2007-0339.R1 \\
\hline Manuscript Type: & Main Section \\
\hline JEL codes: & $\begin{array}{l}\text { P16 - Political Economy }<\text { P1 - Capitalist Systems < P - Economic } \\
\text { Regional Government Analysis < R - Urban, Rural, and Regional } \\
\text { Economics, R58 - Regional Development Policy }<\text { R5 - Regional } \\
\text { Government Analysis < R - Urban, Rural, and Regional Economics }\end{array}$ \\
\hline Keywords: & new economic spaces, collective provision, the state, USA, Europe \\
\hline
\end{tabular}

\section{(s) ScholarONE" \\ Manuscript Central}




\title{
Managing Infrastructural and Service Demands in New Economic Spaces: \\ The New Territorial Politics of Collective Provision
}

\author{
Andrew E.G. Jonas \\ Professor of Human Geography \\ Department of Geography, University of Hull, Hull HU6 7RX, United Kingdom, \\ A.E.Jonas@hull.ac.uk
}

Aidan H. While

Senior Lecturer in Planning Department of Town and Regional Planning, University of Sheffield, Sheffield S10 2TN, United Kingdom

A.H.While@sheffield.ac.uk

\author{
David C. Gibbs \\ Professor of Human Geography \\ Department of Geography, University of Hull, Hull HU6 7RX, United Kingdom, \\ D.C.Gibbs@hull.ac.uk
}

Received November 2007, in revised form June 2008, accepted June 2008 


\begin{abstract}
Research on the geography of urban and regional economic development in the U.S.A. and Europe often emphasizes the contribution of supply-side entrepreneurial local policies to the development and competitiveness of new economic spaces (NES) in and around city-regions. Such policies include public-private partnerships and new forms of regional governance. As hitherto successful NES mature, a newer set of struggles has emerged in particular cities and regions having important clusters of new economic activities. These involve new demands for collective provision of infrastructure, workforce housing and services. Using evidence from Greater Boston in the U.S. and the Cambridge city-region in the U.K., the paper proposes a set of concepts with which to investigate the new territorial politics of collective provision. This politics is an increasingly significant yet under-theorised aspect of the social regulation and competitiveness of NES.
\end{abstract}

Key words: new economic spaces, collective provision, the state, U.S.A., Europe

Andrew E.G. Jonas，Aidan H. While and David C. Gibbs新经济空间基础设施及服 务业需求管理：集体供给的新领域政治学 ( The New Territorial Politics of Collective Provision）, 区域研究。美国和欧洲的城市及区域经济发展地理学研 究通常强调地方政策对城市区域内部及周边新经济空间 (NES) 的发展及竞争 力所作出的贡献。上述政策包括公私合作以及区域管治的新形式。作为截止到 
目前为止成功的NES, 在某些拥有重要的新经济活动簇群的城市与区域已经开

始出现一系列新的矛盾与冲突。这些 (矛盾) 包括对基础设施、劳动力住房及

配套服务的集体供给的新需求。援引来自美国大波士顿地区以及英国剑桥城市

区域的相关证据，本文提出了一系列相关概念用以考察集体供给的新领域政治

学。在NES的社会管治以及竞争力研究方面, 这种政治性日渐显著却未得到充

分的理论化。

Maîtriser la demande d'équipement et de services dans les nouvelles espaces économiques: la nouvelle politique territoriale visant la prestation collective.

Jonas et al.

La recherche sur la géographie du développement économique urbano-régional aux Etats-Unis et en Europe souligne souvent la contribution des politiques locales entrepreneuriales de l'offre au développement et à la compétitivité des nouvelles espaces économiques au sein et autour des cités-régions. De telles politiques incluent des partenariats publics-privés et de nouvelles formes de gouvernance régionale. $\mathrm{Au}$ fur et à mesure que les nouvelles espaces économiques réussies mûrissent, un nouvel ensemble de conflits a fait le jour dans certaines grandes villes et régions qui ont d'importantes grappes de nouvelles activités économiques. Celles-là comportent de nouvelles demandes de prestation d'équipement, de logement social et de services collective. A partir des données pour Greater Boston, aux E-U, et pour la cité-région de Cambridge, au R-U, cet article propose un ensemble de concepts à l'aide duquel on peut examiner la nouvelle politique territoriale de prestation collective. Cette politique est un aspect de plus en plus important, pourtant insuffisamment théorisé, de la réglementation sociale et de la compétitivité des nouvelles espaces économiques.

Nouvelles espaces économiques / Prestation collective / Etat / Etats-Unis / Europe 


\title{
Verwaltung der Nachfrage nach Infrastruktur und Dienstleistungen in neuen Wirtschaftsräumen: die neue Territorialpolitik der kollektiven Beschaffung
}

\author{
Andrew E.G. Jonas \\ Aidan H. While \\ David C. Gibbs
}

\begin{abstract}
Bei der Erforschung der Geografie der urbanen und regionalen

Wirtschaftsentwicklung in den USA und Europa wird oft der Beitrag der lokalen

Unternehmenspolitik auf der Angebotsseite zur Entwicklung und

Wettbewerbsfähigkeit von neuen Wirtschaftsräumen in Stadtregionen und ihrer

Umgebung betont. Beispiele hierfür sind öffentlich-private Partnerschaften und neue Formen der Regionalregierung. Während bisher erfolgreiche neue Wirtschaftsräume reifen, haben sich in bestimmten Städten und Regionen, die über wichtige Cluster neuer Wirtschaftstätigkeiten verfügen, neuere Arten von Bemühungen herausgebildet. Hierzu gehört eine neue Nachfrage nach einer kollektiven Bereitstellung von Infrastruktur, Arbeitnehmer-Unterkünften und Dienstleistungen. Anhand von Belegen aus dem Großraum Boston in den USA sowie aus der Stadtregion Cambridge in Großbritannien schlagen wir in diesem Beitrag verschiedene Konzepte zur Untersuchung der neuen Territorialpolitik kollektiver Beschaffung vor. Diese Politik stellt einen immer wichtigeren, aber zu wenig theoretisierten Aspekt der gesellschaftlichen Regelung und Wettbewerbsfähigkeit von neuen Wirtschaftsräumen dar.
\end{abstract}

Key words:

Neue Wirtschaftsräume

Kollektive Beschaffung

Staat

USA

Europa

\section{Gestión de las demandas de infraestructura y servicios en los nuevos espacios económicos: las nuevas políticas territoriales de dotación colectiva}

Andrew E.G. Jonas

Aidan H. While

David C. Gibbs

Abstract

En el estudio sobre geografía del desarrollo económico urbano y regional en los Estados Unidos y Europa se suele recalcar la contribución de las políticas locales empresariales de suministro para el desarrollo y la competitividad de los nuevos espacios económicos en las regiones metropolitanas y alrededores. Estas políticas incluyen sociedades públicas-privadas y nuevas formas de gobierno regional. Mientras maduran los nuevos espacios económicos, hasta ahora con gran éxito, se han desarrollado nuevos esfuerzos en determinadas ciudades y regiones que disponen de importantes aglomeraciones de nuevas actividades económicas. Esto implica nuevas 
demandas de una dotación colectiva de infraestructura, viviendas para los trabajadores y servicios. Mediante los ejemplos del Greater Boston en los Estados Unidos y la región metropolitana de Cambridge en el Reino Unido, en este artículo proponemos una serie de conceptos con los que analizamos las nuevas políticas territoriales de dotación colectiva. Estas políticas representan un aspecto cada vez más importante, aunque todavía poco teorizado, de la regulación social y la competitividad de los nuevos espacios económicos.

Key words:

Nuevos espacios económicos

Dotación colectiva

El Estado

EE.UU.

Europa

JEL codes: P16 - Political Economy, P1 - Capitalist Systems, P - Economic Systems, R51 - Finance in Urban and Rural Economies, R5 - Regional Government Analysis, R - Urban, Rural, and Regional Economics, R58 - Regional Development Policy, R5 - Regional Government Analysis, R - Urban, Rural, and Regional Economics Classement JEL: P16; P1; P; R51; R5; R; R58 


\section{Introduction}

A substantial and growing body of research on the geography of urban and regional economic development in North America and Western Europe has focussed on the supposed attractiveness of particular territories and locations for the growth of leading-edge technology and knowledge-based manufacturing and service industries (e.g., information and communication technologies, biotechnology, biomedical sciences, the creative industries, and financial services). For instance, there has been a particular fascination for the growth of new industrial spaces in the larger cityregions, which in turn are positioned as territorial drivers of global economic development (CASTELLS and HALL, 1994; GRAY, GOLOB and MARKUSEN, 1996; SCOTT, 1988). In the United States (U.S.), these spaces include fast-growing suburban regions like the Silicon Valley in California and the I-495 region of Greater Boston in Massachusetts. In Europe, examples include Cambridge and the M11 corridor in the United Kingdom (U.K.), suburban developments around Munich (Germany), Stockholm (Sweden) and Helsinki (Finland), as well as some inner-urban developments like the former textile district of Poblenou in Barcelona. Some of these 'new industrial spaces' have matured, whilst others have experienced further bouts of restructuring, growth and expansion, even as a newer generation of industrial districts has appeared across city-regions in Asia (BALASUBRAMANYAN and BALASUBRAMANYAN, 2000; BUNNELL, 2002; CANIËLS and ROMIJN, 2003; PARTHARSARATHY, 2004; PATIBANDLA and PETERSON, 2002; PHILLIPS and YEUNG, 2003).

Research into maturing and emerging industrial districts in the U.S., Europe and Asia has been interested in understanding various aspects of their local-global production dynamics (for a recent overview, see HESS and YEUNG, 2006). This 
research draws upon a range of perspectives and concepts, such as industrial district theory, social capital, the social learning economy, cultural embedding, and transactions-cost approaches (GRAY, GOLOB and MARKUSEN, 1996; HARRISON, 1992; JAMES, 2007; MASSEY, QUINTAS and WIELD, 1992; MORGAN and SAYER, 1988; and see PIKE, RODRÍGUEZ-POSE and TOMANAY, 2006, and STABER, 2007, for comprehensively critical overviews). For the most part, the focus of attention has been on the internal production and labour market dynamics of industrial spaces, whereas in comparison scant attention has been paid to newer forms of territorial governance and state support for collective provision to such spaces.

With respect to the state's role, much of the emphasis has been on documenting the emergence of local entrepreneurial or supply-side territorial policies (CLARKE and GAILE, 1989; EISINGER, 1988; HACKLER, 2003; LAWTONSMITH, 2004; PHILLIPS and YEUNG, 2003). These include inter alia fiscal incentives, incubators, special economic zones, redevelopment districts, provision for skills retraining, investment in 'hard' and 'soft" infrastructure and the corresponding public-private partnerships set up to manage such investment, and new forms of regional governance, amongst other possibilities. The underlying rationale is that by focussing upon factors other than 'traditional' location-factor costs -- e.g., transportation and labour costs -- these arrangements make cities and regions more attractive to firms specialising in the knowledge economy. Nonetheless, quite what happens when the costs of extra provision of infrastructure, housing and services $d o$ rise and threaten the competitiveness of firms operating in these spaces is often not considered, 
It has been suggested that neo-liberalism has exacerbated spatial deficits in social provision and regulation, thereby reinforcing patterns of uneven development at the urban and regional scales (PECK and TICKELL, 2002). Local 'growth coalitions' (LOGAN and MOLOTCH, 1987) have mobilised around various local competitiveness strategies, intensifying demands on the state (including its local and regional branches) to subsidise and promote urban growth, in part, so as to induce regional economic development (COX, 1993; JESSOP, PECK and TICKELL, 1999). Yet such analyses of neo-liberal forms of urban and regional development seem unable to account for the emergence of a newer set of political demands on the part of firms and workers dependent on growth around new economic spaces; demands for additional investments in infrastructure, support services, housing, etc.; in other words, a 'politics of collective consumption' (CASTELLS, 1977). Such demands have become commonplace in city-regions throughout North America and Europe, and are symptomatic of what we shall call a new territorial politics of collective provision.

The paper is organized as follows. Firstly, we argue that the new territorial politics of collective provision represents an important yet under-studied dynamic of governance and state intervention in maturing and growing new economic spaces. Second, we draw upon some concrete examples from recent research in the I-495 region in Greater Boston and the Cambridge city-region in the U.K. and identify some necessary and contingent features of this politics. Third, we outline a heuristic (causal model) of city-regional development showing a tendency to social-regulatory failure around neo-liberal growth spaces, which in turn has given rise to various territorial demands for additional collective provision. Fourth, we contextualize further aspects of this geography by returning to our examples. Here we reflect upon the specifics of 
the city-regional, national and global contexts. In conclusion, we suggest that empirical analysis of struggles around collective provision in mature and emerging high tech spaces in the U.S. and Europe offers a new entry point for theorising wider processes and politics of urban and regional development.

\section{The New Territorial Politics of Collective Provision}

Despite the emergence of political demands and struggles around collective provision in the major city-regions of the global economy, the mainstream literature on new industrial spaces and clusters has not paid much attention to this aspect of regional economic development. Instead, a considerable amount of effort in urban and regional development theory is devoted to understanding the internal (e.g., inter-firm) dynamics of industrial districts and customised high tech spaces, or what can collectively be called new economic spaces (NES). ${ }^{i}$ One of the features of such spaces is a propensity to attract and grow various enterprises specialising in the information and communications technologies, biotechnology and other sectors of the knowledge economy, as well as supporting cultural economies, housing and retail developments, transportation, and other services. Typically, NES occupy suburban locations in globally-connected city-regions, albeit there might be corresponding if not competing, strategies for attracting such developments back into the central city, or to support the growth of clusters around established anchor institutions in the city like research laboratories, universities and hospitals.

Thanks to the work of urban and regional scholars, including inter alia GRAY et al. (1996), HARRISON (1992), MASSEY et al. (1992), SCOTT (1988; 2001), and MORGAN and SAYER (1988), we now know much more about important aspects of the internal production dynamics of the spatial growth hotspots of the global new 
economy. Nonetheless, this knowledge has arguably come at the expense of corresponding appreciation of some of the fiscal, governance and regulatory problems around collective provision that often characterize these mature and emerging centres of high tech production (SAXENIAN, 1989; JONAS, 1996a; 1996b; LEIBOVITZ, 2003). Typical problems include the under-provision of workforce housing, customised infrastructure (water, sewerage, transport, electricity, etc.), sites for new development, parks and open space, schools offering relevant qualifications, customised training facilities, day care, healthcare, and so forth. Some firms provide these services and community facilities as an integral part of their labour control strategies (JONAS, 1996a); but many do not and turn to local public sector institutions to address a lack of local provision of those goods and services seen as necessary for new economy sectors (NEVAREZ, 2003). A key consideration here is how aging infrastructure can be redesigned and upgraded, or new investments occur, which facilitate the circulation of workers, goods, services and knowledge within the NES.

Collective action is necessary to address the infrastructural and service deficits facing NES but the question is whether or not the state is involved. Assuming it is, precisely which territorial branches of the state are implicated is open to struggle and strategic action on the part of a variety of locally dependent interests (COX and MAIR, 1988; COX and JONAS, 1993). Given a proclivity for the state to pursue neoliberal economic policies (TICKELL and PECK, 2002) there is pressure on local and regional state capacities to follow suit and drive down location-specific costs. In this context, demands for additional investments in infrastructure, housing and other services appear to work against the grain not least in terms of bucking a widespread 
trend towards location cost-reduction strategies and inter-territorial competition in economic development policy (see MALECKI, 2004).

Although the many small-to-medium sized firms that comprise the new economy might individually not place huge additional investment demands on the state and its territorial branches, the spatial clustering and growth of firms, workers and a whole host of support activities and services around cities and regions does generate such demands (cf. SAXENIAN, 1994). In fact, NES-dependent firms operating in different local jurisdictions across the same city-region might place competing demands on the same collectively-provided urban and regional infrastructure and services. Political decisions have to be made about which new expenditures and demands across a city-region are to be prioritised, and how to fund these collectively through various new structural and territorial arrangements in urban and regional government (PIVEN and FRIEDLAND, 1984).

By the same token, a nation state or a provincial-cum-regional government interested in supporting a particular NES in a given city-region will want to target that city-region for extra public investments in infrastructure and services in the hope it can back a likely winner in the international competition to generate jobs, wealth and taxes. The resulting extra collective-provision demands that are imposed on state fiscal capacities around the one city-region must be weighed against the corresponding underinvestment in services and infrastructure across the other cityregions of a state's territory.

Although access to low-cost infrastructure and services has always been important to urban and regional development, conventional explanations for the development of NES have had surprisingly little to say about the new territorial politics of collective provision. It is generally assumed (rather than being subject to 
empirical scrutiny) that firms and investors operating in NES automatically benefit from the kinds of localised external transaction costs, flows of goods and information, and positive social and environmental externalities that typify the competitive local industrial milieu. By implication, it is also assumed that local and regional territorial branches of the state responsible for providing infrastructure and services to NES are aware of the importance of quality above that of cost. Therefore they avoid internalising the sorts of transaction costs and political demands that are often associated with other arguably 'less productive,' 'older' or 'less entrepreneurial' firms and sectors, not just within the same city-region but also presumably other cityregions in a state's territory.

Nevertheless, theories of the economics of public service provision and collective consumption have recognized that under certain circumstances territorial competition promotes service-delivery efficiencies (TIEBOUT, 1956; BISH, 1971). Such theories predict that mobile investments, jobs and people are always likely to relocate to local jurisdictions that are able to respond to match local service provision levels to local quality of life demands. Such demands, it is argued, reveal income, class and sector-specific preferences (TIEBOUT, 1956). One might infer that the new infrastructural and service demands to be found in NES are simply expressing new sector-specific preferences. Yet as we now argue, there are a range of other political and economic dimensions of 'quality of life' that ought to be factored into the local spatial development milieu. We need to revise, rethink and update existing approaches to the public economy of city-regions. 


\section{Approaching the New Territorial Politics of Collective Provision}

It has long been recognised that capitalist growth puts demands on a city or region's physical and social infrastructure in terms of land scarcity, traffic congestion, house price inflation, and demands on the local tax base (HARVEY, 1985: 125-164). Growth induces urban agglomeration effects that can benefit local producers and consumers; but as we have argued urban and regional development in turn generates externalities and costs for workers and firms. In today's global city-regional economies, it appears that there is an endemic failure to internalise the economic, social and environmental costs of new forms of growth due largely to the lack of development of corresponding state and governance capacities (SCOTT, 2001). However, this is not to say that businesses organisations, trades unions, community and citizen groups, housing associations, and transportation interests are not politically active. On the contrary, across cities, suburbs and entire regions demands on behalf of local business interests are expressed almost on a daily basis for the enhancement of local and regional infrastructural and governance capacities (JONAS and PINCETL, 2006).

In focussing upon how cities and regions can compete to attract new economic activity, conventional theories often fail to acknowledge the ongoing importance of demands for collective provision to the economic development of NES. ${ }^{\text {ii }}$ Indeed, one might anticipate that one longer-term effect of supply-side forms of spatial development has been the accumulation of a structural-regulatory deficit in meeting or regulating demand around collective provision at particular locations and sites of growth across city-regions.

While some researchers have studied the new forms of infrastructure to be found in city-regions (GRAHAM and MARVIN, 2001), the mainstream literature 
continues to prioritise the new generation of supply-side models of territorial economic governance, especially those that reduce the costs of doing business locally. These include various forms of competitive regionalism in the U.S. (CLARKE and GAILE, 1998; JONAS and WARD, 2002), and so-called 'soft' regionalism in Europe (MORGAN, 1997), albeit the new regionalist orthodoxy currently sweeping spatial development theory has not been without its critics (LOVERING, 1999; MACLEOD, 2001). In light of these growing criticisms, there seems to be a good case for situating certain aspects of research on NES growth trajectories within a more abstract critical analysis of the role of the state and collective provision (HARRISON, 2007; WARD and JONAS, 2004).

By the same token, insofar as there has been any attention paid to the social needs and demands of the knowledge workforce (CRANG and MARTIN, 1991; GRAY et al., 1996), much of this remains couched in terms of supply-side discourse and rhetoric. To take one influential example, FLORIDA (2002) suggests that the long-term success of NES depends on the continuing attractiveness of city-regions to workers with requisite skills and creative talents. Implicit in this argument is the view that quality of life, social mix, and the social integration of workers are central to the supply-side dynamics underpinning city-regional competitiveness. Although the creative-class thesis has been a focus of some critical analysis in the literature (NEVAREZ, 2003; McCANN, 2007), the basis of such critique has evidently not been founded upon its chronic neglect of collective provision, i.e. aspects of the demand-side cost considerations shaping class relations and local growth politics in capitalist growth regions.

All-in-all, we know surprisingly little in terms of the range and variety of growth-related demands associated with NES; nor about the new territorial politics of 
collective provision across any given city-region. Such knowledge might not only shed light on the changing geography of the state under neo-liberalism but also invite consideration of the extent to which new state geographies reflect new or alternative political and economic rationalities (e.g., neo-Keynesian, the 'Third Way,' liberal progressive, environmental and social sustainability, ecological modernisation, etc.). To be sure, the intensity of conflict around a given city-region might well reflect regulatory failure in those modes of state social provision constructed under neoliberal rules and conditions. So examining different geographies of neo-liberalism is certainly a part of the story (TICKELL and PECK, 2002); but only a part. In addition, a fairly detailed empirical knowledge of local and regional state geographies operating under historic or new and different development pressures and modes of social regulation (e.g., developmental, postcolonial, regionalist, federalist, etc. modes) might equally be required. Such differences in local and regional geographies of the state are important in mediating between the concrete spatial interests of NESdependent firms and workers, on the one hand, and the wider (national) politics of collective provision, on the other (COX, 2002).

We now briefly demonstrate the changing nature of demands for collective provision and accompanying state territorial adjustments by reference to two examples taken from two quite different contexts: Boston in the U.S.; and Cambridge in the U.K.. These examples are presented in a somewhat schematic fashion in order to illustrate our conceptual approach. Suffice it to say that detailed research is underway in both places, as well as in a wider sample of NES, which we hope will lend further support to our claim that the new territorial politics of collective provision is an important yet under-researched feature of local and regional economic development in NES. 


\section{Geographies of Collective Provision in New Economic Spaces in the U.S. and Europe}

Boston's high tech-driven city-regional growth: Crisis of housing affordability and finding revenue for regional infrastructure renewal

Alongside Silicon Valley in California, the Boston metropolitan area has been cited in various studies as an example of a successful high tech growth city-region in the U.S. For example, the 2007 State New Economy Index ranked Massachusetts ${ }^{\mathrm{iii}}$ top of the league table of U.S. States according to its measure of economic development (ATKINSON and CORREA, 2007). This measure takes into account the number of high value-added jobs created and retained rather than traditional measures of economic development (e.g., number of corporate branch-plant relocations or 'smokestack chasing'). As the largest city-region in Massachusetts, Boston has obviously played a key role in the development of the new economy across the State. Early growth around computer and defence-related sectors in the 1960s and 1970s has been succeeded by new forms of growth around ICT, biotech, and biomedical and financial services. A recent study by YU (2003) ranks Boston fourth after Chicago, Washington DC, and the Silicon Valley, respectively, in terms of the US metropolitan area with the highest total of high tech jobs.

Notwithstanding the material significance of the knowledge economy, Boston's economy remains quite diversified relative to that of its 'competitors' (i.e., other U.S. States or even new international growth centres like Dublin in Ireland). The basis for this diversity lies in the retention of some traditional jobs in manufacturing industry as well as the growth of retail, biomedical and financial services. Some new growth has happened along the Route 128 suburban ring 
immediately surrounding the City of Boston but more importantly further west along the I-495 corridor and extending out to the City of Worcester and neighbouring towns and suburbs. Since the 1980s, many of these outer-urban communities have seen significant transformations in the local politics of economic development: from local forms of corporate welfare to the current emphasis on attracting new service, biomedical and high technology industries, many of which have since come under external (foreign) ownership (JONAS, 1992).

Although new forms of high tech and related employment growth are spread throughout the Boston city-region, our present focus is the 32 towns and suburbs along the I-495 corridor (Figure 1). As we will argue, due to the strong presence of NES interests this sub-region of the larger Boston metropolitan area has begun to develop a separate regional economic and political identity. Significantly, this development is accompanied not so much by attempts to attract capital and investment to the region (i.e., territorial competition) but local and regional demands for collective provision. An important regional player in managing these new demands is the 495/MetroWest Corridor Partnership, a non-profit economic development organisation which was established in 2003 to represent the interests of firms, local chambers of commerce and the local government jurisdictions in this part of the Boston city-region. ${ }^{\text {iv }}$

$$
* * * \text { Figure } 1 \text { about here } * * *
$$

In terms of the wider context, NES-related demands for collective provision in the I-495 region have come in the wake of attempts by the State to promote the more usual array of supply-side forms of economic development. In this respect, Massachusetts' fiscal crisis of 1990-91 was represented as especially damaging to the competitiveness of established high tech interests along the Route 128 corridor, and 
accelerated the structural decline in manufacturing jobs State-wide. In response to this particular crisis, reform-minded business groups searched for new fiscal and regulatory supply-side solutions to what they saw as various economic development challenges. The result was a move to promote a stronger competitiveness agenda across the State's economic regions in part to overcome perceived failures and threats to new economy industries and the financial services sector based in Boston (JONAS, 1996b). In Boston, there had been a particular emphasis on supply-side economic development projects around improving local and regional transport infrastructure (e.g., the so-called 'Big Dig' tunnel linking the suburbs, airport and downtown) as well as the promotion of various mega-project developments like new sports stadia and regional shopping and entertainment centres (HORAN and JONAS, 1998). These projects might have strengthened the economy of downtown Boston but arguably did not benefit the more deprived inner-urban communities; nor for that matter did they address the spatial needs of established manufacturing centres and NES in the outer parts of the city-region.

Some sectors and firms operating in the I-495 region continue to struggle to compete in what is still seen as an unfriendly regional business climate. Yet from an economic development perspective the primary concern is how to manage growth rather than how to devise a competitive tax and regulatory regime that supports Boston-based sectors or manufacturing State-wide, albeit it could be agued that fortunes of the two are inter-related. For local interests in NES in outer Boston in particular, two significant areas of economic development concern are promoting housing affordability for entry-level knowledge and service-sector workers and provision of high quality infrastructure for locally-based firms. 
In the case of addressing problems of workforce housing affordability, the issue is often constructed as one of supply but that this, in turn, is underpinned by growth-related demands. The latter tend to be specific to the local jurisdictions served by NES. In terms of the politics, there is a particular concern that addressing demands for workforce housing is not to be confused with the provision of social housing across the State more generally since in any case 'affordability' is uneven between local political jurisdictions. Here, the fragmentation of the city-region into independent self-governing municipalities and towns is seen to be part of the problem rather than the solution:

Massachusetts housing activist: The first thing [is] supply. Massachusetts is a very high- barrier-to-entry housing market. Among other things, we have 351 cities and towns, each of which is a separate political jurisdiction. So that each of those cities and towns sets its own zoning, sets its own design standards. And there is a huge amount of what we call here Not-In-My-BackYardism (NIMBYism) going on, so that it is very, very difficult to produce new housing. Arguably juxtapositioned [sic.] against that, we have the longest and most productive history in the country of producing subsidized housing for low income people. Part of that is because when those programs began in the late 1960s and 1970s we had a cadre of real estate developers in Boston, who, for whatever reason, were interesting in taking advantage of government programs, and we had an existing housing stock which was the oldest in the country [and in need of] rehabilitation. (Interview, September, 2007, our insert.)

In terms of unlocking these barriers to supply in suburban areas, attention is focussed upon State laws and regional growth management policies. A particular 
focus of ongoing conflict is Chapter 40B. ${ }^{\mathrm{v}}$ First enacted in 1969, Chapter 40B is the State of Massachusetts' so-called 'anti-snob' or 'affordable housing' law, which requires suburban municipalities to relax zoning and enable the development of higher density affordable single-family housing. This law over-rides 'local control' in regards to land use authority, enables municipalities to produce more housing on smaller lots than the more typical half acre and single acre lots, and thereby promotes housing affordability. In the I-495 region, it has been championed by housing developers and activists alike as a way of resolving a backlog of housing construction in suburban areas to meet NES-driven demands.

However, housing provision is not the only growth-related issue in the I-495 region. New house-build in outer suburban areas creates a demand for services and schools on the part of the middle classes and those seeking employment in new economy sectors. In Massachusetts, the difficulty of meeting these demands locally is

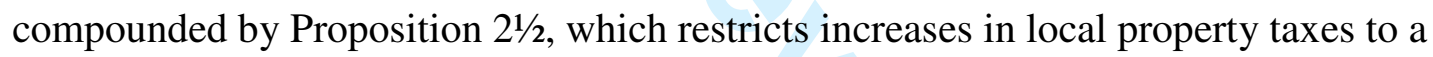
$2.5 \%$ annual increase regardless of the assessed market value of property. Suburbs facing revenue pressures might once have opposed the construction of affordable housing at the lower end of the market (e.g., due to fears of promoting 'racial turnover'). Today, however, such opposition is not so much an issue to be constructed around 'race' -- since, for example, Boston area public schools are no longer under a court-ordered program of desegregation -- but is framed quite explicitly in class terms. The argument is that restrictions on new housing development make it difficult for entry-level workers to afford housing close to work. Here NES growth interests have been able to connect problems of regional economic development to a class politics of collective provision. 
In this, there is an opportunity to construct a powerful counter argument to those who might oppose the construction of so-called affordable housing in established suburbs. Credence can be given to claims to the effect that building more housing in the suburbs to meet employers' demands redistributes wealth more equitably regardless of whether property values are rising or falling (the latter has become a more acceptable part of the new territorial discourse in light of the 'crisis' in subprime mortgage lending). This is because workers will not have to devote such a significant proportion of their income to the costs of commuting if homes can be built closer to work. For firms and their allies in the house-building sector, recasting the politics of collective provision as a problem of regional (in)equity offers a powerful weapon in brokering conflict with, on the one hand, State and regional organisations that want stronger regulation and growth management and, on the other, taxpayers and existing homeowners interested in repealing Chapter 40B. ${ }^{\mathrm{vi}}$

A second area where collective provision becomes important in the politics of local and regional development in Massachusetts is the debate about infrastructure renewal. This has been festering for a number of years but in our research we find that it has intensified into a full-scale regional 'infrastructure crisis'. According to the recently-established Transportation Investment Coalition, which is comprised of Boston-based business organisations, trades unions and transportation agencies, the infrastructure crisis can be costed at $\$ 20$ billion as the estimated deficit State-wide in funding for infrastructure renewal. ${ }^{\text {vii }}$ Although finding revenue for future investment in infrastructure is a concern for taxpayers, transport providers and business and industry organisations throughout the State (and indeed the U.S.), from the standpoint of I-495 firms the issues are more concrete. The debate is much more focussed around reducing travel costs for high tech and service firms and workers within the region. 
The strategy is to improve connections between towns and suburbs along the I-495 and adjoining local routes, along with further improvements to regional transport so that workers can spend less time and money on commuting to jobs.

The challenge is how to connect these place-specific needs to wider demands across the city-region for transit-orientated developments, affordable housing and infrastructural renewal. Access to Federal funding for infrastructure renewal has become a new battleground, but in the past the high tech sector in Boston has discouraged any debate about raising taxes to fund infrastructure and services (JONAS, 1996b). The result is a vibrant new territorial politics of infrastructure renewal, with arguments now constructed around, for example, how much Massachusetts commuters and taxpayers pay in the form of taxes on the sale of fuel compared to those in other States, and how much the State receives in turn in Federal transportation dollars.

Subsumed within this is another economic development discourse specific to NES interests in the I-495 region. This involves the relationship between -- or politics of -- funding infrastructural renewal in the suburbs, on the one hand, and building cooperation between various regional transport and planning organisations involved in delivery, on the other. Here it could be argued that recent Federal support for investments such as the infamous 'Big Dig' project have tended to privilege links between the city's airport, the inner suburbs and downtown Boston, including the city's established biomedical and financial sector firms. From the standpoint of suburban high tech interests, the solution to the 'infrastructure crisis' is not a question of making Boston per se more attractive to knowledge workers or the creative class (FLORIDA, 2002). Nor is it necessarily a question of enabling Massachusetts to compete with other States through tax policy. Rather it is a more concrete set of 
concerns; new policies and state territorial structures are needed to build affordable and workforce housing, address local infrastructural issues, and retain and attract the workforce to meet a growing demand locally for entry-level high tech and service jobs specifically in suburban spaces. Promoting supply-side economic development policies and attracting firms and knowledge workers to the city distracts attention from these more localised growth problems. In other words, there are likely to be different spatial interests at stake in meeting the collective-provision demands of NES. Yet such conflicts-of-interest (e.g., among business factions) are often not taken into consideration, especially in neo-classical and neo-institutional approaches to territorial competition.

\section{The Cambridge Phenomenon and 'Invest in Success'}

A growing emphasis on meeting demands for collective provision also shapes struggles around new centres of NES development in the UK's relatively prosperous and growing South East region, particularly around the Peterborough-CambridgeStansted M11 Corridor (or what might be called the Cambridge 'city-region'). The rapid growth of the Cambridge economy in the 1990s -- what became known as 'The Cambridge phenomenon' (see CRANG and MARTIN, 1991) -- led to some heated debates around collective provision. The issues here were the provision of sites to allow local firms to expand, new housing for the workforce, especially housing affordable to so-called 'key workers' (see RACO, 2008), basic infrastructure and other support services. The debates have intensified as the Phenomenon moves into what has been described in a consultancy report as a 'second phase' of growth (PACEC, 2003). As with the Boston example discussed above, the main point we want to make here is that the politics of collective provision in Cambridge has become 
inseparable from the politics of economic development. However, there are some important differences in the way this politics works through the specific geographies and regulatory assemblages of the U.K. state.

From the standpoint of interests speaking for high tech industries, the university and service firms which talked up a Cambridge 'growth crisis' in the late 1990s and early 2000s helped to focus local state attention around a lack of governance capacity around collective provision (WHILE, JONAS and GIBBS, 2004a). These governance and regulatory failures involved not just constraints within existing local and national planning frameworks (e.g., green belt policy) and local government structures (e.g., state spending restrictions on local government) but also a structural crisis of under-provision in regard to housing and supporting infrastructure. The argument has been that inward investors and entrepreneurs need to be located close to the geographic centre of the 'phenomenon' in order to access the cluster of research parks, support services and infrastructure found there. In this context, various local high tech interests and their allies in local government have begun to talk of the need to 'invest in success' (GCP, 2001), or risk losing investment to rival international NES destinations.

Moreover, it is in this context that 'place entrepreneurs' (LOGAN and MOLOTCH, 1987) have made the not-unconvincing argument that 'Cambridge' suffers from a financial as well as infrastructural deficit, and that the crisis of underprovision remains a threat to the city-region's economic sustainability on a European scale. The deficit refers to apparent shortfalls in state expenditures on infrastructure, transport, water, sewerage, police, health and education in relation to what Cambridge and its region contributes through taxes on economic growth. Indeed, a focus of ongoing struggle has been the Standard Spending Assessment (SSA), which is a 
negotiated mechanism for allocating central government fiscal support to counties based on various demographic and economic factors and current service needs, and accounts for the majority of locally controlled finance. The issue here is the creation of a funding mechanism for capital expenditures on infrastructure and key services so as to accommodate future growth in the sub-region, something which the SSA formula for Cambridgeshire as a whole apparently does not take into consideration: Andy Jonas: So [there] is the argument about the infrastructure deficit. So what's the politics of that?

Cambridgeshire County Official: The SSA [standard spending assessment] argument is about basic core services, care of the elderly, pupil-teacher rations ... We've got an extremely low SSA, particularly compared with our immediate neighbours because there are area cost adjustments. So there is a feeling that our core services are under-funded. But that is the recurrent spending. This debate is about capital and investment; the two of course are interrelated, but here it is about the investment needed. In actual fact, we've always been a revenue-poor County because of the SSA (we've been not rich, but moderate as a County Council), but what we've never seen is any large-scale investment to go with growth... It's a governance issue, in this mishmash where there was no leadership from anywhere because everyone's got diffused responsibilities, who's taking responsibility for making this $£ 2$ bn. happen, who’s taking responsibility for making these 70,000 houses happen, who's taking responsibility for quality, who's taking responsibility for making sure it is sustainable?

Aidan While: It's interesting because the story could be seen as being central government unblocking the city, but it seems to be more about local responses. 
County Official: Exactly, yes. What helped a great deal on the way is [the regional] Government Office, and they have been absolutely super - they've been totally tuned not only to the needs of the area but also to the sensitivities of national politics, so they've known when to intervene, how to intervene. Without that we wouldn't have got very far (Interview, August, 2002, our insertions).

So even in the context of a more centralised territorial structure such as the U.K. state, there is an emergent politics of collective provision. Crucially, in this case it is a politics that has been selectively constructed as a politics of territorial scale. In order for Cambridge to continue to grow and compete as a NES, it is necessary to construct arguments in scalar-territorial terms that are fiscally advantageous. One solution is to exploit existing social class and consumption sector-driven fiscal disparities across a wider territory -- in this case the entire county -- in order to make the political case for extra investment for the Cambridge 'city-region'.

We suspect the situation in Cambridge where new connections have been made -- albeit selectively and strategically in terms of class, territory and scale -between the politics of collective provision and local and regional development is not unusual for mature and emerging high tech regions. However, there are some important differences between our two examples. In Boston, the debates about collective provision are framed very much in terms of the fragmented political geography of the U.S. state at the metropolitan scale (COX and JONAS, 1993). Here, for instance, overcoming problems of suburban political exclusion and metropolitan fiscal disparity lend credence to arguments for creating more effective forms of regional governance. In Cambridge, the debates about resolving growth challenges in the city and the wider region seem to illustrate the challenges of state centralism for producing a more competitive polycentric U.K. state (MORGAN, 2007). Yet the 


\section{Approaching the New Territorial Politics of Collective Provision}

As our examples show, addressing the growth needs of NES involves sustaining and enhancing the existing and future levels of provision of infrastructure and services. We have called this the new territorial politics of collective provision. It involves inter alia demands from: locally dependent firms for collective provision of infrastructure (water, sewerage, improved transport links, etc.) and other services (e.g., developable land); workers of all different social classes and incomes (i.e. not just elite knowledge workers) for social consumption in the living place (e.g., affordable housing, good schools, environmental amenities, etc.); and from the local and regional public authorities (e.g., for additional local taxes, grants, voter-approved bond issues, and revenue from higher levels of government). These demands have different implications for how economic development institutions manage problems of collective provision in their service territories. Moreover, the geography of the state is important in shaping how these demands map concretely onto space.

We now are in a better position to propose a heuristic (or conceptual model) of the role of spaces of collective provision in the politics of global city-regional development (Figure 2). We start out by noting the necessary possibility for the existence of spaces of under-provision. These spaces can be defined as those cityregional economies where there is a failure to generate the infrastructures and services seen as necessary for sustaining NES. These might include workforce housing, hard 
and soft infrastructure, transportation, land use, and related services. Identifying spaces of under-provision (and related demands for extra-provision) could be associated with the corresponding over-development of local firm-level production capacities, or overzealous national government policies to establish sites for NES without supporting fiscal resources. Alternatively, it could simply be a locallyexpressed need for extra provision on top of initial investments so as to keep up with the competition in the same city-region or elsewhere.

***Figure 2 about here***

NES exhibiting such political-regulatory 'failures' will have a sudden proliferation of state and non-state actors and agencies devoted to addressing the problem of lack of provision (or social regulation of) basic infrastructure. To put this somewhat differently, the development of what has been described as 'institutional thickness' (see, e.g., AMIN, 1994) around spaces of collective provision could be as much a sign of structural-institutional weaknesses as it is of economic success.

Underpinning all of this is the need for growth interests to find alliances, build political support and develop new governance capacities around specific territories. This may be a case of business interests selecting strategic allies in local civil society or the local state, or drawing in support from other social classes, around existing state territorial structures, and constructing in the process new structures -- for example, by building the economic development case for a new civic regionalism (JONAS and PINCETL, 2006). Conversely it might be the case of elected politicians, planners, policymakers or local residents taking the lead in forging a governance agenda on the basis of environmental and quality-of-life concerns (e.g., promoting sustainable forms of transport). The possibilities are many and varied, and give rise to all sorts of hybrid state-market forms of collective provision and state territorial structures. 
Here we are further reminded of arguments about the tendency or even the necessity in capitalism for alliances to form around particular territories (HARVEY, 1982). For Harvey, the incentive for building cross-class territorial alliances comes from the material threats posed by capital's inherent spatial mobility to various forms of immobility: those in particular pertaining to fixed investments in social and physical infrastructure. We can now augment this with the idea that territorial coalitions are formed in places (and around state territorial scales) in ways that aim to generate extra state and private infrastructural and service investment and jobs in the long term. So here the agenda is additional collective provision and the anticipated higher returns on future state investments in social consumption and provision:

As space relations alter in response to transport [and related infrastructural] investment, so do the relative fortunes of capitalists in different locations. Some suffer devaluation of labour power, their fixed capital and consumption fund (housing, etc.) while others enjoy, temporarily at least, excess profits and upward revaluation of available means of production and consumption (HARVEY, 1982: 378, our insert and emphasis)

One might further hypothesise that the case for additional fiscal or regulatory support for NES from the state becomes couched in terms of ideas of a moral space economy (see COX, 1999). This is important when the growth problems facing some NES are compared and contrasted to the fortunes of others, or when support for one city-region is required even when there are obvious deficits in state welfare and infrastructure provision at others. It is important to demonstrate that what might be seen as rational and equitable for one NES (because it has already proven its net national or regional social worth) is, likewise, good for others, when these others are in the same city-region or maybe elsewhere, in which case the definition of scale, 
region and territory becomes more "stretched out" and "socially inclusive" (JONAS, 2006). It might further be necessary for those interests dependent on NES growth to anticipate counter-arguments (against further investment or state support) in moral spatial terms on the grounds that other interests likewise dependent on welfare and collective provision might be more deserving of state support. Here it is important for NES interests to incorporate -- albeit selectively and strategically -- contemporary discourses of social inclusion, regional equity and environmental sustainability so as to make the case. We believe that new social and environmental sustainability discourses are most likely to found in those city-regions where NES interests are able to identify a severe collective provision 'crisis'. Crisis, in turn, shapes new forms of collective action, which reinforce, underpin or perhaps at times conflict with a politics of economic development constructed relentlessly around territorial competition.

\section{Some Additional Territorial Dimensions of the Politics of Collective Provision}

It is apparent from all of this that the management of the politics of collective provision in NES can pose immense organizational and legitimacy problems not just for firms but also the national state. Tensions centre upon maintaining circuits of investment in localised NES growth sectors (including provision of additional basic services and infrastructure) and managing problems of uneven development in the wider national territory (e.g. addressing housing affordability more generally across the state's territory). As our examples suggest, such problems are particularly acute in places with particular concentrations of new economic sectors (e.g., suburban areas of Boston or semi-rural areas around freestanding university cities like Cambridge) since in many respects these are often seen as already economically, fiscally and socially privileged spaces. The challenge is how to construct a politics of collective provision 
in terms that prompt the state (along with other agencies) to channel resources, investments and fiscal capacities to these places and away from other arguably equally deserving and under-serviced spaces. All of this suggests the importance of contextualizing our argument with respect to particular historical conditions and national social contexts, which we will now attempt.

\section{Collective provision and regulating the capital-labour relation}

First of all, there is a need to address the historically contingent form of the politics of collective provision in the overall process of social regulation in capitalism (AGLIETTA, 1979). By definition, NES are maturing or emerging spatial forms of capital accumulation, which in turn generate particular needs, struggles, conflicts, and demands around labour control (JONAS, 1996a). Collective provision is a factor here: firms must develop new infrastructural and service capacities and community facilities in order to integrate their workforces into the production system effectively and in a non-conflictual fashion. Given that the particular labour and infrastructure requirements of NES are not in the first instance met locally, crises of collective provision are likely to be instrumental to wider struggles around the social regulation of the capital-labour relation. Social regulatory issues likely to be displaced to the wider space economy include: maintaining wages and income levels attractive to workers in the knowledge economy; upgrading skills in these and related sectors; spatially integrating workers into the national production system; supporting and sustaining labour's consumption fund, etc. Some issues will remain localised such as: seeking further improvements in conditions in the living space; maintaining the quality of infrastructure and the local environment (parks, recreation, and open space); facilitating the supply of labour through housing, transport, schools, health 
provision, and so on; and more generally meeting the demands of local firms, residents and workers for socially adequate or 'high quality' services.

By definition, these social regulatory and labour control considerations have only recently become issues characteristic of NES. It is perhaps not surprising that the corresponding regulatory structures are weakly developed. It takes time for firms, business and industry groups and relevant actors to respond to the territorial challenges of new forms of growth and development; in fact they can be quite hostile to state intervention initially. For instance, high tech industry in suburban Boston has in the past operated as a free-rider when it came to matters of collective provision especially at the State-level (SAXENIAN, 1989). The sector was at best indifferent if not in fact outspoken and generally anti-government, anti-taxation and anti-regulation (i.e., its political rhetoric was broadly in tune with neo-liberal supply-side national economic policy). It was left to other reformist manufacturing and business organisations based around Boston to engage in economic development policy (JONAS, 1996b). This attitude has changed:

Andy Jonas: Thinking about economic development, how would you characterise how that has changed in the last few years in the Massachusetts' context? Are you talking about economic development from the standpoint of a cost factor or quality of life?

Massachusetts business organisation representative: I think is a change over the last decade or more. Clearly, the competition nationally and internationally has probably been the biggest paradigm shift. If you take a look a decade or so ago, it was pretty much that businesses had to be in Boston... Not quite so simple, but in essence it was a little bit more of case where we don't have to do as much because there is so much of a demand coming in here not to need to create incentives and 
such like that. Well, clearly that's not totally true but that was the attitude. That attitude sort of collapsed, probably around 1990 when we had a recession here; that was certainly a breaking point... that was for a lot of us the warning sign that we have a serious problem, and that if we don't start to become much more competitive, stacking ourselves up head-to-head with some of these other States coming here on a daily basis recruiting companies that have 50 more employees to come to their State with a lot of incentives. The interesting thing is of course that financial incentives are part of the deal closer. Companies don't move just because of financial incentives but they will move because of the human resources or the other kind of resources they need... but if you're looking for high quality talent [Boston] is a place to be, but now there are other places to be, and we have to compete against that. So, the competition nationally and internationally has become the real kick-off for us to try to look critically at what we are doing. (Interview, September, 2007, our insert.)

\section{New spaces of governance around collective provision: the politics of city- regionalism}

To the extent that the new territorial politics of collective provision is becoming a driver of NES growth, our arguments also speak to recent work on new geographies of city-region governance. This is more than a case of building local economic development networks amongst local firms but crucially also alliances with various city and regional authorities and community organisations involved in mediating interests dependent on NES; interests in the labour market, land use planning, housing, infrastructure, healthcare and perhaps even welfare. If there is an ongoing reliance upon supply-side measures (new taxing authorities, special purpose 
districts, public-private partnerships, and the like), the political case for these still has to be made and this increasingly requires constructing new partnerships and coalitions around addressing deficits in infrastructure and collective provision across the wider city-region.

In both of our examples the politics of collective provision has resulted in new alliances and institutional developments and a deepening of the division of labour across the city-region. ${ }^{\text {vii }}$ At the heart of this is a politics of organising an appropriate or functional (that is, for capital) scalar division of labour in the state (COX and MAIR, 1991). In a more centralised state like the U.K., responsibility for economic development has been partially devolved to the regional and sub-regional levels, as also to some extent has responsibility for delivery of services. Our Cambridge example also reveals how the politics of collective provision can be up-scaled geographically within the city-region in order to connect NES needs to wider demands for welfare provision in the territorial state.

In a Federal state like the U.S., there are attempts by metropolitan and regional organisations to draw down responsibilities and powers from State and Federal government. In the suburbs of Boston, there remains scope for local fiscal autonomy but the parochialism of local government creates problems; hence the interest in creating new forms of regional governance appropriate for NES development. Yet despite the growing strength of the New Regionalism, there is little evidence even in a paradigmatic NES such as the I-495 region in Greater Boston that what has resulted amounts to a "structurally coherent" city-regional form of governance. Instead, cityregions like Greater Boston are becoming territorially fragmented in new and complex ways. At the same time, fiscal relations and struggles around Federal, State, 
regional and local territorial structures have become if anything more fluid, contested and complicated.

What seems to be a thread common to both our examples is the increasingly central role of the politics of collective provision in economic development. Such a politics makes conditions of economic success or failure of NES as much a matter of struggles around state geography as one of the (lack of) development of self-contained regulatory capacities.

\section{Collective provision and the politics of social globalization}

So far we have concentrated on institutions and regulatory processes specific to two NES, one in the U.S. and the other in the U.K.. In that respect, we could be accused by the likes of WOOD and VALLER (2004) of an obsession with the form rather than substance of local institutionalism. Indeed, it might even be argued that our examples offer further evidence in support of what PECK and TICKELL (2002) call a shift from the 'roll-back' phase of laissez-faire deregulation in the 1980s to a new and softer phase of 'roll-out' neo-liberalism designed to account for some of the earlier social contradictions and crisis tendencies of unfettered market-based economic deregulation. At one level we would not disagree with such criticisms and observations. Yet are we talking about new spatial forms of neo-liberalism or perhaps instead altogether different forms? In other words, are we talking about radically new territorial-political rationalities and forms of collective action around NES? It seems that our examples point to counter-tendencies in the neo-liberal project and, indeed, can perhaps be marshalled to dispute some assumptions upon which claims are made about the politics of space as being colonised by spaces of neo-liberalism to the exclusion of all other territorial rationalities. 
We feel that certain representations of the current regulatory transition as dominated by supply-side policy frameworks that seem to fit an over-arching neoliberal spatial hegemony could benefit from a more explicit spatialisation. There is, for instance, a relation between the place-specific politics of collective provision and the wider 'politics of globalisation' (COX, 2002). The politics of globalisation involve a dominant shift in spatial politics (i.e., demands on the state) towards the supply-side and competing on an international stage for globally mobile capital; a shift that privileges, in particular, multinational capitals and nation states, but also implicates urban and regional players including property developers and local financial firms $(\mathrm{COX}, 1993) .{ }^{\text {ix }}$ Yet our argument is that various new challenges (not so much to the neo-liberal project as to the profits of local firms and the incomes of workers) are appearing from within the very spaces that appear to have benefited most from globalisation. The further development of NES requires interventionist policies despite globalisation. We might call demands for such policies the new territorial politics of social globalisation. An example of the politics of social globalisation is the 'Third Way' model of territorial development promoted by advocates of a new 'social' Europe. This model “...counters the adverse effects that globalization can have on inequality and the low skilled, but at the same time is open to the world and invests in the future" (LIDDLE, 2006: 291).

Consider in this light the origins of new forms of state intervention around collective provision in the growth areas of Europe. In the U.K., market-led deregulation has exposed contradictions in the neo-liberal project and has been come to be opposed or questioned at least by the very geographic interests it was designed to support: those of financial sector and new economy firms in London and the South East. What 'New Labour' (the Labour Government under former Prime Minister 
(P.M.) Tony Blair and the current P.M., Gordon Brown) has in part been about has been addressing the social under-regulation of the capital-labour relation: investing in housing and infrastructure; providing income support; investing in communities; and the like. Here the Labour Government has been quite explicit about the necessity of the state's role in managing in the politics of collective provision. Of course, private interests remain at the heart of this (e.g., encouraging investment in the housing market and relying upon state-regulated private finance initiatives) so finding a right balance between state and market has not always been easy. If the 'Thatcher years' of social deregulation were built around driving down the social costs of labour and privatising collective provision, in the new political economy this is not enough (PECK and TICKELL, 1995).

In the national political calculus around sustaining collective provision places like Cambridge now become important for driving forward the U.K. state's ongoing commitment to the new European social economy, and for maintaining its competitive advantage internationally. This means, not just collaborating with places in Western Europe like Helsinki, Stockholm, Munich, Barcelona, or Sophia Antipolis, but also with NES elsewhere. New Labour has an important weapon for securing support for its wider social project from NES interests that have not always been sympathetic to growth. The weapon is housing on a mass scale, and in particular to address claims of shortages resulting from the so-called 'not-in-my-back-yard' (N.I.M.B.Y.) attitudes of (e.g., Conservative Party-controlled) district local authorities and residents. This apparently is dampening the supply of 'key workers' (e.g., workers in sectors such as education, health, the police and the like) crucial to economic success (RACO, 2008). Thus the national political significance of the crisis of under-provision in Cambridge is not that (as supply-siders or adherents to the 
creative class thesis might suggest) 'local politics' interferes with the attractiveness of the place for very highly-skilled or elite workers, place entrepreneurs, and the like, and that this threatens its 'success' or 'creativity'. Rather it is the lack of state intervention around collective provision that diminishes the supply of all categories and social classes of workers by making it socially impossible for low and middle income households to move to or live in these places. Not surprisingly, questions of 'quality of life' are couched increasingly in concrete terms that resonate with national priorities: for example, optimizing the 'social mix' in new house build, increasing the social housing stock, and balancing new growth against environmental issues like water shortages and loss of open space. ${ }^{\mathrm{x}}$

In the Boston example, the presence of a politics of social globalisation is not so obvious. Nonetheless long-standing national social tensions do appear to underpin important divisions around the more contentious local growth issues like funding urban infrastructure, overcoming the legacy of racial and class segregation in the suburbs, attempting to reduce lower and middle class dependence on automobiles, and switching to carbon-neutral investments in alternative forms transport (e.g. commuter rail). In particular, where access to Federal funding is at stake struggles around the spatial politics of mobility and immobility associated with various forms of NES development are becoming more commonplace. This could have important implications for examining the new ways in which business groups find political allies across the city-region, both in the public sector and in civil society (cf.

HENDERSON, 2004). ${ }^{\mathrm{xi}}$ 


\section{Conclusions}

This paper has attempted to draw out some possible links and connections between urban and regional development and what we have called the new territorial politics of collective provision. In terms of its contribution to conceptualizing urban and regional development in the U.S., the paper has three points to make. First, recent institutional approaches to local economic development have afforded causal priority to the governance structures and agents that mediate between local sites of investment and wider geographies of capital mobility. Notably there has been the important work on growth coalitions (LOGAN and MOLOTCH, 1987) and post-federal local entrepreneurialism (CLARKE and GAILE, 1998); work which by-and-large has emphasised the contribution of public-private partnerships and regional governance in mediating supply-side economic development. Without dwelling on details, we can say that this work has (to the extent that it has been interested in collective provision) by-and-large emphasised the role of the state as one of facilitator or steering agent, serving as the local broker and risk-taker in meeting supply-side needs and bankrolling the assets of hyper-mobile capital (cf. JESSOP, PECK and TICKELL, 1999). The clear beneficiary in all of this is capital, whether it is in the form of industrial clusters, firms and development interests dependent on new economy spaces, or prospective inward investors; in other words, localised capitals operating in global markets and networks. But not so much other agents, especially local states, social movements, workers, lower and middle class consumers, and of course those seeking housing and work, the unemployed, underemployed, and the servicedependent.

Second, if there has been some attention to the geographic form of the state in recent urban and regional development theory, it is often seen as derivative of wider 
capitalist forces of economic growth and the neo-liberal project rather than a product of local demands for collective provision. Here the direction of causality works not simply 'downwards' from the international and national levels through the territorial hierarchies and structures of the state to the city-regional level (e.g., to putative cityregional state formations) but also laterally across the economic landscape, perhaps as networks, flows and externally-orientated forms of governance. These bind NES and city-regions into wider networks and regulatory frameworks, albeit in a spatially uneven fashion. What little space there is in all of this for understanding the contractions and regulatory tensions within and around NES -- for the give-and-take of agency, politics and conflict -- is broadly subsumed within a discourse of the hegemonic needs of global capital and the banal institutional landscapes created by neo-liberal regulatory forms. A clearer sense of contestation and conflict around fiscal flows and investments in social and physical infrastructure across a city-region is fast being eviscerated from the intellectual landscape of urban and regional development. It seems as if NES appear magically, utterly detached from their formative and contested city-regional and national social formations.

Third, and by extension, there is a danger that knowledge of how the needs of workers and households working and living around NES are negotiated and managed on a day-to-day basis is analytically shoved to one side (WARD and JONAS, 2004). Likewise, knowledge of the attendant social and gender divisions around consumption sectors and income groups is not always central to the analysis of city-regional development dynamics (JARVIS, 2007). Yet our argument is that NES interests cannot be so easily detached from other spaces of welfare and social provision.

Are these surprising conclusions? It would seem they should not be. After all, the production of goods and services in capitalism is regulated by the profit motive 
rather than the fulfilment of human needs and requirements; the latter could conceivably be met through alternative (including non-capitalist) social and economic forms (LEYSHON, LEE and WILLIAMS, 2003). If new forms of capitalism (i.e., new economy firms) could function and operate without having to worry about social and physical investments and the social conditions of reproduction of labour power, then they would certainly do so. Yet in many of our examples, it is business interests (and their political allies) which have taken up the social (collective) provision cause with zeal and they have found willing partners in certain state agencies, environmental organisations, community groups and different sectors dealing with labour's reproduction, indeed in some cases with labour itself. The result has often been what we have identified as a new territorial politics of collective provision.

In our future work on NES in the U.S.A., Europe and Asia, we shall be investigating in further depth the new territorial politics of collective provision. In the meantime, there are two remaining issues to consider. First, there is the issue of how matters relating to the politics of collective provision have been relatively neglected in the urban and regional development literature. It could be that struggles around the state for collective provision have been increasingly displaced away from demands on economic development and production, but this in turn only intensifies the fiscal crisis of the (local) state (PIVEN and FRIEDLAND, 1984). This begs the question as to how the collective provision needs of NES are met in the longer term without exposing local and regional state institutions and actors to a crisis of democratic legitimacy.

Second, there is the need to address the question: how new is the territorial politics of collective provision? It is insufficient simply to report a structural neglect of collective consumption as a particular feature of contemporary approaches to neo- 
liberal urban growth regimes (COCHRANE, 1999). In fact, our research suggests that contemporary discourses of social inclusion and environmental sustainability have come much more into play in the politics of urban and regional development, whereas national government policy in countries like the U.S. and U.K. continues to emphasise fiscal conservatism and anticipate business (and voter) opposition to significant tax increases. In this context, recent attempts to represent NES as sustaining a particular 'quality of life' for the creative class or responding voluntarily to national and global challenges of environmental and social sustainability need to be treated with a great deal of caution. By looking more closely at the new collective-provision demands of NES, there lies an opportunity to rethink conventional approaches to economic development, not least that have focussed relentlessly upon supply-side territorial policies to the exclusion of demand-side considerations.

Acknowledgments: The support of the British Academy (Grant No. SG-45293) is gratefully acknowledged. Thanks to the reviewers and to the editors of this special issue for some very helpful comments. John Garner prepared Figure 1 from an original supplied by the 495/MetroWest Corridor Partnership, for which we are grateful. We also express our gratitude to the individuals in Boston and Cambridge who agreed to be interviewed for this project. In accordance with ethics guidelines, we have preserved anonymity when using direct quotes. We would be pleased to correct errors of fact in subsequent papers. 


\section{References}

AGLIETTA M. (1979) A Theory of Capitalist Regulation. London, New Left Books.

ALLEN J. and COCHRANE A. (2007) Beyond the territorial fix: regional assemblages, politics and power Regional Studies 41, 1161-1176.

AMIN A. (Ed) (1994) Post-Fordism: A Reader. Blackwell, Oxford.

ATKINSON R. and CORREA D. (2007) The 2007 State New Economy Index:

Benchmarking Economic Competition in the States. Washington DC, The Information and Technology Foundation, February. [Available to download on http://www.kauffman.org/items.cfm?itemID=766 (Ewing Marion Kauffman Foundation).]

BALASUBRAMANYAN V. and BALASUBRAMANYAN A. (2000) The software cluster in Bangalore, in J. H. DUNNING (Ed) Regions, Globalization and the Knowledge-Based Economy, pp. 349-363. Oxford University Press, Oxford.

BISH R.L. 1971 The Public Economy of Metropolitan Areas. Markham Series in Public Policy Analysis, Chicago.

BUNNELL T. (2002) Multimedia utopia? A geographical critique of high-tech development in Malaysia's Multimedia Super Corridor Antipode 34, 265295.

CANIËLS M. and ROMIJN H. (2003) Dynamic clusters in developing countries: collective efficiency and beyond, Oxford Development Studies 31, 275292.

CASTELLS M. (1977) The Urban Question. MIT Press, Cambridge MA.

CASTELLS M. and HALL P. (1994) Technopoles of the World: The Making of $21^{\text {st }}$ Industrial Complexes. London, Routledge. 
CLARKE S. and GAILE G.L. (1989) Moving towards entrepreneurial state and local development strategies Policy Studies Journal 17, 574-598.

CLARKE S. and GAILE G.L. (1998) The Work of Cities. Minneapolis, MN, The University of Minnesota Press.

COCHRANE A. (1999) Redefining urban politics for the twenty-first century, in A.E.G. JONAS and D. WILSON (Eds) The Urban Growth Machine: Critical Perspectives Two Decades Later, pp. 109-124. SUNY Press, Albany, NY.

COURCHESNE C. (2004) What regional agenda?: Reconciling Massachusetts's affordable housing law and environmental protection, Harvard Environmental Law Review 28, 215-247.

COX K.R. (1993) The local and the global in the New Urban Politics: A critical view. Environment and Planning D: Society and Space 11, 433-48.

COX K.R. (1999) The growth machine and ideologies of community, in A.E.G. JONAS and D. WILSON (Eds) The Urban Growth Machine: Critical Perspectives Two Decades Later, pp. 21-36. SUNY Press, Albany, NY.

COX K.R. (2002) Political Geography: Territory, State and Society. Blackwell. Oxford.

COX K.R. and JONAS A.E.G. (1993) Urban development, collective consumption, and the politics of metropolitan fragmentation Political Geography 12, 8-37.

COX K.R. and MAIR A.J. (1988) Locality and community in the politics of local economic development Annals of the Association of American Geographers 78, 307-325.

COX K.R. and MAIR A.J. (1991) From localised social structures to localities as agents Environment and Planning A 23, 197-213. 
CRANG P. and MARTIN R.L. (1991) Mrs Thatcher's vision of the 'new Britain' and the other sides of the 'Cambridge phenomenon' Environment and Planning D: Society and Space 9, 91-116.

EISINGER P. (1988) The Rise of the Entrepreneurial State Madison, WI, University of Wisconsin Press.

FLOOD J. and KABLACK M.A. (2008) Affordable housing recap and forecast, Massbuilder First Quarter, 22.

FLORIDA R. (2002) The Rise of the Creative Class New York, Basic Books.

GRAHAM S. and MARVIN S. (2001) Splintering Urbanism London, Routledge.

GRAY M., GOLOB E. and MARKUSEN A. (1996) Big firms, long arms, wide shoulders: the hub-and-spoke industrial district in the Seattle region Regional Studies 30, 551-666.

GCP (GREATER CAMBRIDGE PARTNERSHIP) (2001) Investing in Success: Action Plan Cambridge, GCP.

HARRISON B. (1992) Industrial districts - old wine in new bottles. Regional Studies 26, 469-483.

HARRISON J. (2007) From competitive regions to competitive city-regions: a new orthodoxy, but some old mistakes Journal of Economic Geography 7, 311332.

HACKLER D. (2003) High-tech location in five metropolitan areas Journal of Urban Affairs 25, 625-640.

HARVEY D .W. (1982) The Limits to Capital Oxford, Blackwell.

HARVEY D.W. (1985) The Urbanization of Capital Baltimore, Johns Hopkins Press.

HENDERSON J. (2004) The politics of mobility and business elites in Atlanta, Georgia Urban Geography 25, 193-216. 
HESS M. and YEUNG H.W-C. (2006) Whither global production networks in economic geography? Environment and Planning A 38, 1193-1204.

HORAN C. and JONAS A.E.G. (1998) Governing Massachusetts: uneven development and politics in metropolitan Boston Economic Geography (Special issue for the Annual Meeting of the Association of American Geographers), 83-95.

JAMES A. (2007) Everyday effects, practices and causal mechanisms of 'cultural embeddedness': learning from Utah's high tech regional economy Geoforum 38, 393-413.

JARVIS H. (2007) Home truths about care-less competitiveness International Journal of Urban and Regional Research 31, 207-214.

JONAS A.E.G. (1992) Corporate takeover and the politics of community: the case of Norton Company in Worcester Economic Geography 68, 348-372.

JONAS A.E.G. (1996a) Local labour control regimes: uneven development and the social regulation of production Regional Studies 30, 323-338

JONAS A.E.G. (1996b) In search of order: traditional business reformism and the crisis of neoliberalism in Massachusetts Transactions of the Institute of British Geographers 21, 617-634.

JONAS A.E.G. (2006) Pro scale: further reflections on the scale debate in human geography Transactions of the Institute of British Geographers 31, 399-406.

JONAS A.E.G. and PINCETL S. (2006) Rescaling regions in the state: the New Regionalism in California Political Geography 25, 482-505.

JONAS A.E.G. and WARD K. (2002) A world of regionalisms? Towards a US-UK urban and regional policy framework comparison Journal of Urban Affairs 24, $377-401$. 
KRUEGER R. and GIBBS D. (forthcoming) 'Third Wave' sustainability? Smart growth and regional development in the U.S. Regional Studies.

LAWTON-SMITH H. (2004) The financing of innovation: institutional support for high tech industry in Oxfordshire, in A. WOOD and D. VALLER (eds) Governing Local and Regional Economies: Institutions, Politics and Economic Development, pp.121-146. Aldershot, Ashgate.

LEIBOVITZ J. (2003) Institutional barriers to associative city-region governance: the politics of institution-building and economic governance in 'Canada's Technology Triangle' Urban Studies 40, 2613-2642

LEYSHON A., LEE R. and WILLIAMS C. (Eds) (2003) Alternative Economic Spaces Sage, London.

LIDDLE R. (2006) A common social justice policy for Europe, in A. GIDDENS, P. DIAMOND and R. LIDDLE (eds) Global Europe, Social Europe, pp. 279298. Cambridge, Polity.

LOGAN J.R. and MOLOTCH H.L. (1987) Urban Fortunes: The Political Economy of Place University of California Press, Berkeley.

LOVERING J. (1999) Theory led by policy? The inadequacies of the 'new regionalism' in economic geography illustrated from the case of Wales International Journal of Urban and Regional Research 23, 379-395.

MACLEOD, G. (2001) The new regionalism reconsidered: globalization, regulation and the recasting of political economic space International Journal of Urban and Regional Research 25, 804-829.

MALECKI E. (2004) Jockeying for position: what it means and why it matters to regional development policy when places compete Regional Studies 38, 11011120. 
MASSEY D., QUINTAS P. and WIELD D. (1992) High-tech Fantasies: Science Parks in Society, Science and Space. Routledge, London.

McCANN E.J. (2007) Inequality and politics in the creative city-region: questions of liveability and state strategy International Journal of Urban and Regional Research 31, 188-196.

MORGAN K. (1997) The learning region: institutions, innovation and region renewal Regional Studies 31, 491-503.

MORGAN K. (2007) The polycentric state: new spaces of empowerment and engagement? Regional Studies 41, 1237-1252.

MORGAN K. and SAYER A. (1988) Microcircuits of Capital. Cambridge, Polity.

NEVAREZ L. (2003) New Money/Nice Town: How Capital Works in The New Urban Economy. Routledge, New York.

ODPM (Office of the Deputy Prime Minister) (2003) Sustainable Communities Building for the Future. ODPM, London.

PACEC (Public and Corporate Economic Consultants) (2003) The Cambridge Phenomenon: Fulfilling the Potential (on behalf of Greater Cambridge Partnership, Cambridgeshire County Council and East of England Development Agency). PACEC, Cambridge.

PECK J. and TICKELL A. (1995) The social regulation of uneven development: 'regulatory deficit', England's South East and the collapse of Thatcherism Environment and Planning A 27, 15-40

PECK J. and TICKELL A. (2002) Neoliberalizing space Antipode 34, 380-404

PATIBANDLA M. and PETERSON B. (2002) Role of transnational corporations in the evolution of a high-tech industry: the case of India's software industry, World Development 30, 1561-1577. 
PHILLIPS S.A.M. and YEUNG H.W-C. (2003) A place for R\&D? The Singapore Science Park Urban Studies 40, 707-732.

PIKE A., RODRÍGUEZ-POSE A. and TOMANAY J. (2006) Local and Regional Development. London, Routledge.

PIVEN F.F. and FRIEDLAND R. (1984) Public choice and private power: a theory of fiscal crisis, in A. KIRBY, P. KNOX and S. PINCH (Eds) Public Service Provision and Urban Development, pp.390-420. New York, Croom Helm/St. Martins.

RACO M. (2008) Key worker housing, welfare reform and the new spatial policy in England Regional Studies 42, 737-751.

SAXENIAN A. (1989) In search of power: the organization of business interests in Silicon Valley and Route 128 Economy and Society 18, 25-70.

SAXENIAN A. (1994) Regional Advantage: Culture and Competition in Silicon Valley and Route 128. Harvard University Press, Cambridge, MA.

SCOTT A.J. (1988) Flexible production systems and regional development: the rise of new industrial spaces in North America and Western Europe International Journal of Urban and Regional Research 12, 171-186.

SCOTT A.J. (2001) Global City-Regions: Trends, Theory, Policy. Oxford, Oxford University Press.

STABER U. (2007) Contextualising research on social capital in regional clusters International Journal of Urban and Regional Research 31, 505-521.

TIEBOUT C.M. (1955) A pure theory of local expenditures Journal of Political Economy 64, 416-424

WHILE A., JONAS A.E.G. and GIBBS D. (2004a) Unblocking the city: 
growth pressures, collective provision and the search for new spaces of governance in Greater Cambridge, England Environment and Planning A 36, 279-304.

WHILE A., JONAS A.E.G and GIBBS D. (2004b) The environment and the entrepreneurial city: the 'sustainability fix' in Manchester and Leeds International Journal of Urban and Regional Research 28, 549-569

WARD K. and JONAS A.E.G. (2004) Competitive city regionalism as a politics of space: a critical reinterpretation of the New Regionalism Environment and Planning A 36, 2119-2139.

WOOD A. and Valler D. (2004) Governing local and regional economies, in A. WOOD and D. VALLER (eds) Governing Local and Regional Economies: Institutions, Politics and Economic Development, pp.1-21. Aldershot, Ashgate.

YU P.D. (2003) Focus on high tech Regional Review 14, 6-9. 
Figure 1

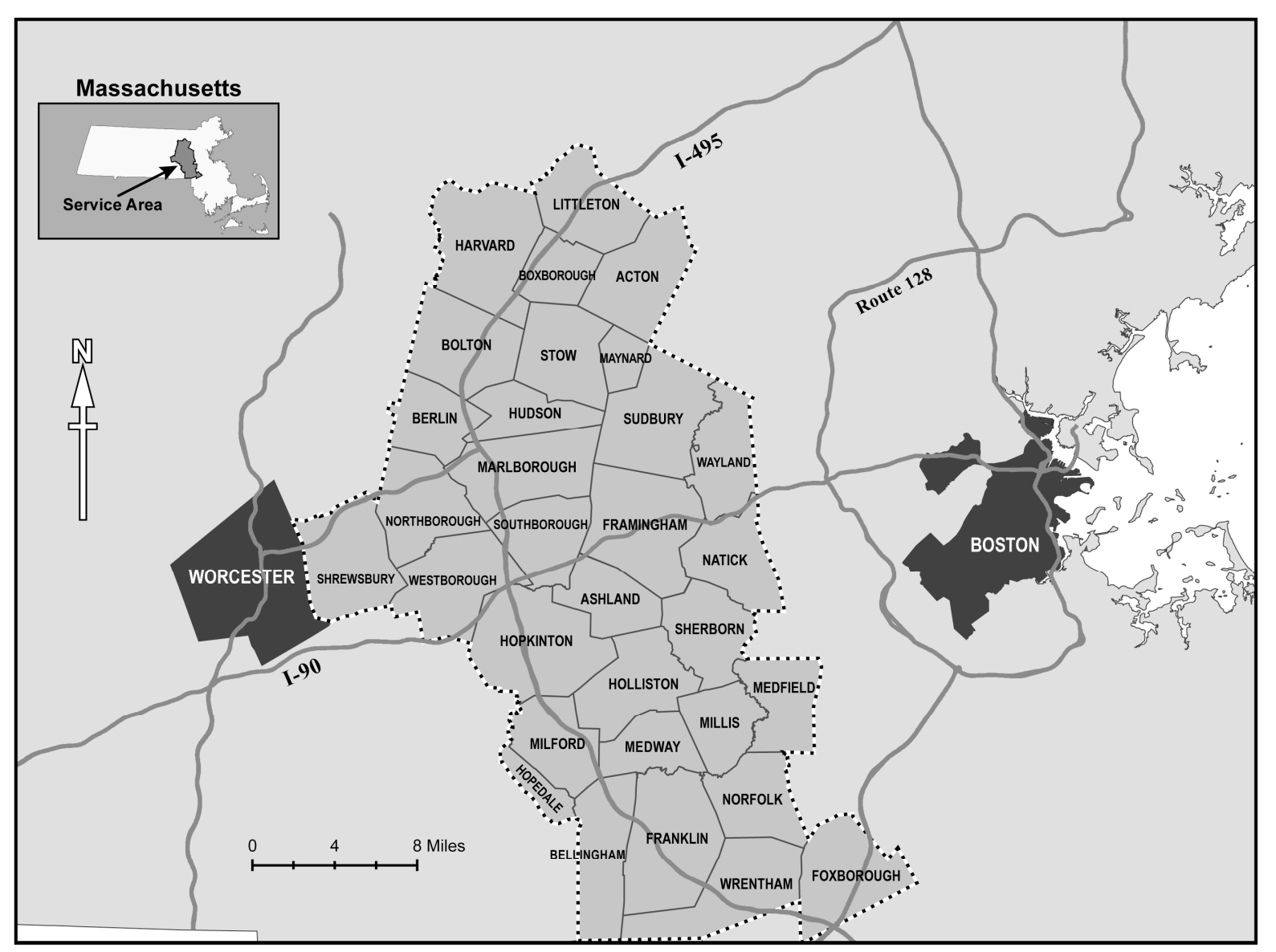

Figure 1 : The I-495/MetroWest Corridor Partnership Service Area. ～( Redrawn from original supplied by 495/MetroWest Corridor Partnership by permission.) 
Figure 2

\section{NEW ECONOMIC SPACES AND CITY-REGIONAL} DEVELOPMENT

\section{Supply-side driven}

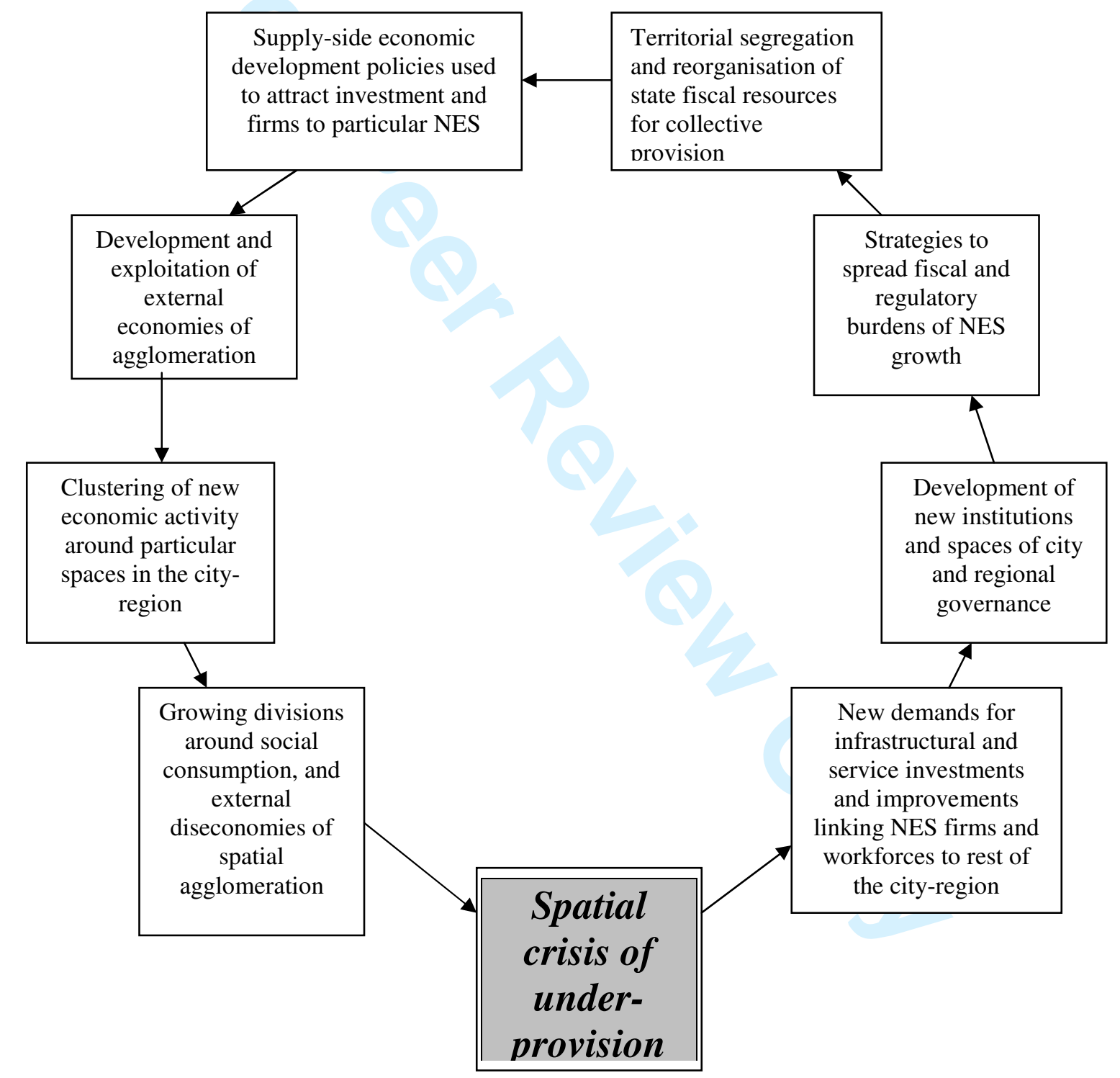

Figure 2: A heuristic of the relationship between the spatial politics of collective provision and city-regional development 


\title{
Notes
}

\begin{abstract}
${ }^{\mathrm{i}}$ Although many readers will be familiar with terms such as new industrial spaces and clusters, we prefer to use the expression 'new economic spaces'. This is because we are interested not so much in industrial agglomeration or clustering per se as in the demands for infrastructure and services associated with developing and sustaining particular NES.

${ }^{\text {ii }}$ In our previous research, we have examined new forms of urban and regional development in terms of the territorial politics of environmental and social sustainability (WHILE, JONAS and GIBBS, 2004a; 2004b).

${ }^{\text {iii }}$ For the purposes of this paper, we use the term State when referring to the Commonwealth Government of Massachusetts. Below the State level, there is no unitary or single government authority for the Boston city-region. Instead the region is fragmented into numerous local municipalities operating under a system of local home rule. Metropolitan planning authorities and regional business organisations have been set up to deliver planning, infrastructure and housing on a regional and quasicooperative basis. KRUEGER and GIBBS (forthcoming) describe in some detail the increasingly important role of these metropolitan institutions in promoting more environmentally sustainable forms of development across the Boston city-region. ${ }^{\text {iv }}$ See http://www.arc-of-innovation.org/, first accessed August 2007. The Boston cityregion has a rich and well-developed institutional landscape devoted to economic governance, albeit there are ongoing tensions amongst the different business interest groups and factions representing high tech industry, on the one hand, and manufacturing and services, on the other (JONAS, 1996b). The 495/MetroWest Corridor Partnership was set up to represent the interests of new economy firms, which were not being met effectively through existing local arrangements including
\end{abstract}


local chambers of commerce and local jurisdictions. It was felt that more of a regional approach was required to address growth-induced infrastructural, planning and housing needs of local employers, both small and large (Interview with regional economic development practitioner, September, 2007).

${ }^{\mathrm{v}}$ For a number of years, Chapter 40B has been a particular focus of struggle in the politics of growth State-wide in Massachusetts (see COURCHESNE, 2004, for a fuller discussion of this law).

${ }^{\text {vi }}$ The viewpoint of I-495 house-builders is nicely illustrated by FLOOD and KABLACK (2008: 22): "Neighborhoods restrict the growth of new apartments or prevent subdivisions, which causes the demand for housing to disperse over larger areas (sprawl), and drives housing and commuting prices higher...This trend is very evident within the Route 495 area..., where there is virtually no undeveloped multifamily zoned land available outside of cities". An attempt to repeal Chapter 40B in December 2007 failed to garner sufficient signatures to appear on a State-wide ballot measure.

${ }^{\mathrm{vii}}$ From information provided at Transport Strategy Forum held at the Suffolk Law School, Boston, on $14^{\text {th }}$ September, 2007 (attended by Andy Jonas).

${ }^{\text {viii }}$ For example, a new partnership has emerged in Cambridgeshire to address the infrastructure deficit. Cambridgeshire Horizons developed out of the former Cambridgeshire Infrastructure Partnership. It is responsible for delivering some 47,500 new homes and $£ 2.2 \mathrm{bn}$ of support infrastructure in the Cambridge sub-region by 2016, using the Cambridgeshire Structure Plan as a strategic framework and drawing into funds available for housing and community provision from the Labour government's Sustainable Communities programme (see http://www.cambridgeshirehorizons.co.uk, first accessed March, 2005). 
${ }^{\text {ix }}$ Similar sorts of concerns underpinned older industrial centres in the nineteenth century. For example, COX (2002: 270-2) comments on how the "social imperialism" promoted by British Prime Minister Joseph Chamberlain sought to protect Birmingham based manufacturers from international competition. This policy conflicted with trade liberalisation favoured by London-based companies. ${ }^{\mathrm{x}}$ Unreconstructed supporters of neo-liberal supply-side solutions might argue that demand has been met by the deregulation of monetary policy and freeing interest rates from state control by allowing the Committee on Monetary Policy at the Bank of England to set them. This was a pet policy of Gordon Brown, the former U.K. Chancellor and now Prime Minister. Yet as 'key workers' and other consumers of housing in NES like Cambridge become overleveraged with mortgage debt and interest rates rise, or as younger entrants to the labour market are unable to afford homes, this would present a national electoral problem for the Labour Government and for Gordon Brown. The politics of collective provision would hit back in national elections (cf. PECK and TICKELL, 1995, on Thatcherism and the South East, the UK's other 'problem region'). Likewise in the U.S., the recent crisis in the sub-prime mortgage lending market has exposed weaknesses in the social regulation of financial firms that have profited from investing in metropolitan housing markets in the 1990s and early 2000s.

${ }^{x i}$ In our wider research project, which is looking at the debates and coalitions forming around infrastructure and workforce housing in Boston, Seattle and Denver, there are emerging tensions between different sectors of the housing development industry, with growing pressure (from national developers and the regional business community) on local housing developers to invest in the 'affordable' sector. This usually means building 'workforce housing' around new transit development hubs 
located in both the central city and the suburbs. The national Urban Land Institute has been an important advocate of such policies in each of these cities. 


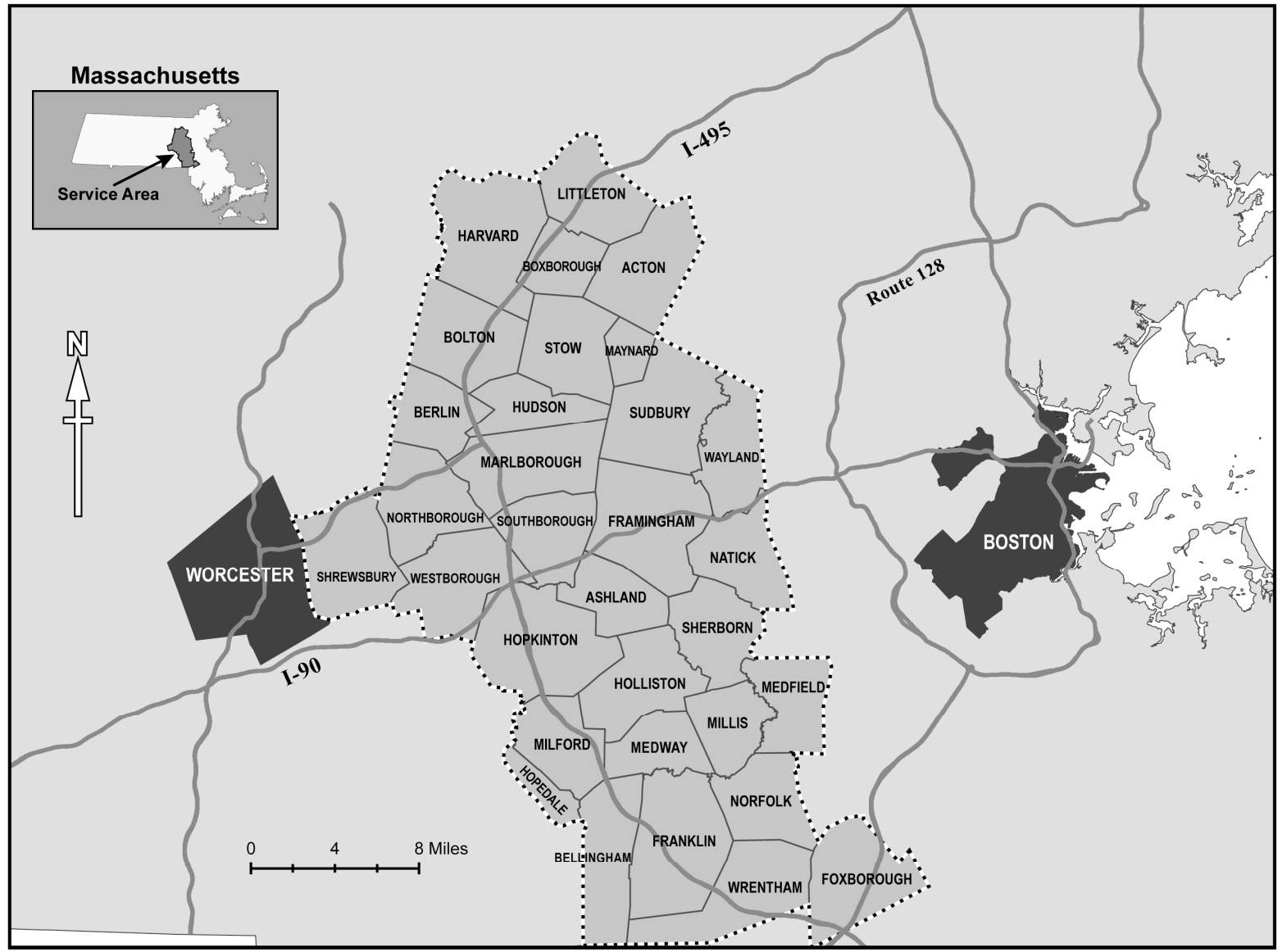

Figure 1 : The I-495/MetroWest Corridor Partnership Service Area. （ Redrawn from original supplied by 495/MetroWest Corridor Partnership by permission.) 


\section{NEW ECONOMIC SPACES AND CITY-REGIONAL} DEVELOPMENT

\section{Supply-side driven}

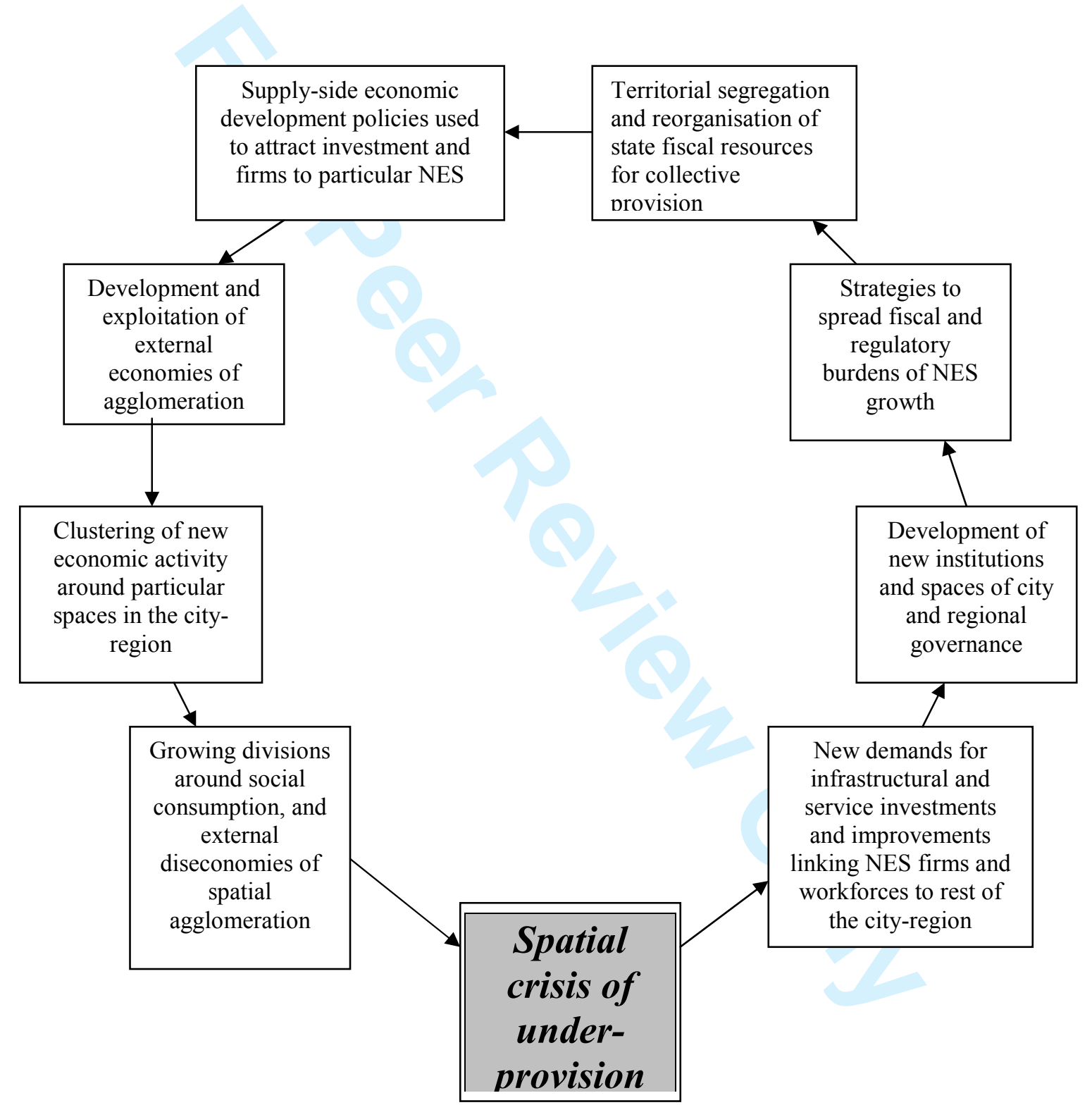

Figure 2: A heuristic of the relationship between the spatial politics of collective provision and city-regional development 


\title{
Managing Infrastructural and Service Demands in New Economic Spaces:
}

\author{
The New Territorial Politics of Collective Provision \\ Andrew E.G. Jonas \\ Professor of Human Geography \\ Department of Geography, University of Hull, Hull HU6 7RX, United Kingdom, \\ A.E.Jonas@hull.ac.uk
}

Aidan H. While

Senior Lecturer in Planning Department of Town and Regional Planning, University of Sheffield, Sheffield S10 2TN, United Kingdom

A.H.While@sheffield.ac.uk

\author{
David C. Gibbs \\ Professor of Human Geography \\ Department of Geography, University of Hull, Hull HU6 7RX, United Kingdom, \\ D.C.Gibbs@hull.ac.uk
}

Revised for Regional Studies (June, 2008)

\begin{abstract}
Acknowledgments gratefully acknowl $\mathrm{d}$. Thanks to the reviews and the editors of this special issue for some very helpful comments. We also express our gratitude to the individuals in Boston and Cambridge who agreed to be interviewed for this project. In accordance with ethics guidelines, we have preserved anonymity when using direct quotes. We would be pleased to correct errors of fact in subsequent papers.
\end{abstract}




\begin{abstract}
Research on the geography of urban and regional economic development in the U.S.A. and Europe often emphasizes the contribution of supply-side entrepreneurial local policies to the development and competitiveness of new economic spaces (NES) in and around city-regions. Such policies include public-private partnerships and new forms of regional governance. As hitherto successful NES mature, a newer set of struggles has emerged in particular cities and regions having important clusters of new economic activities. These involve new demands for collective provision of infrastructure, workforce housing and services. Using evidence from Greater Boston in the U.S. and the Cambridge city-region in the U.K., the paper proposes a set of concepts with which to investigate the new territorial politics of collective provision. This politics is an increasingly significant yet under-theorised aspect of the social regulation and competitiveness of NES.
\end{abstract}

Key words: new economic spaces, collective provision, the state, U.S.A., Europe 


\section{Introduction}

A substantial and growing body of research on the geography of urban and regional economic development in North America and Western Europe has focussed on the supposed attractiveness of particular territories and locations for the growth of leading-edge technology and knowledge-based manufacturing and service industries (e.g. firms specialising in information and communication technologies, biotechnology, the creative industries, and financial services). For instance, there has been a particular fascination for the growth of new industrial spaces in the larger cityregions, which in turn are positioned as territorial drivers of global economic development (CASTELLS and HALL, 1994; GRAY, GOLOB and MARKUSEN, 1996; SCOTT, 1988). In the United States (U.S.), these spaces include fast-growing suburban regions like the Silicon Valley in California and the I-495 region of Greater Boston in Massachusetts. In Europe, examples include Cambridge and the M11 corridor in the United Kingdom (U.K.), suburban developments around Munich (Germany), Stockholm (Sweden) and Helsinki (Finland), as well as some inner-urban developments like the former textile district of Poble Nou in Barcelona. Some of these “new industrial spaces” have matured, whilst others have experienced further bouts of restructuring, growth and expansion, even as a newer generation of industrial districts has appeared across city-regions in Asia) (BALASUBRAMANYAN and BALASUBRAMANYAN, 2000; BUNNELL, 2002; CANIËLS and ROMIJN, 2003; PARTHARSARATHY, 2004; PATIBANDLA and PETERSON, 2002; PHILLIPS and YEUNG, 2003).

Research into maturing and emerging industrial districts in the U.S., Europe and Asia has been interested in understanding various aspects of their local-global production dynamics (for a recent overview, see HESS and YEUNG, 2006). This 
research draws upon a range of perspectives and concepts, such as industrial district theory, social capital, the social learning economy, cultural embedding, and transactions-cost approaches (GRAY, GOLOB and MARKUSEN, 1996; HARRISON, 1992; JAMES, 2007; MASSEY, QUINTAS and WIELD, 1992; MORGAN and SAYER, 1988; and see PIKE, RODRÍGUEZ-POSE and TOMANAY, 2006, and STABER, 2007, for comprehensively critical overviews). For the most part, the focus of attention has been on the internal production and labour market dynamics of industrial spaces, whereas very little attention has been paid to newer forms of territorial governance and state support for collective provision to such spaces.

With respect to the state's role, the emphasis hitherto has been on the emergence of local entrepreneurial or supply-side territorial policies (CLARKE and GAILE, 1989; EISINGER, 1988; HACKLER, 2003; LAWTON-SMITH, 2004; PHILLIPS and YEUNG, 2003). These include inter alia fiscal incentives, incubators, special economic zones, redevelopment districts, provision for skills retraining, public and private investments in both "hard" and "soft" infrastructure, and new forms of regional governance, amongst other possibilities. The underlying rationale is that by focussing upon factors other than "traditional” location costs -- e.g., transportation and labour costs -- these arrangements make cities and regions more attractive to firms specialising in the knowledge economy. Nonetheless, quite what happens when the costs of extra provision of infrastructure, housing and services do rise and threaten the competitiveness of firms operating in these spaces is often not considered,

Nevertheless $\underset{\underline{\underline{E}}}{\underline{\underline{P}}}$ is been suggested that neo-liberalism has exacerbated spatial deficits in social provision and regulation, thereby reinforcing patterns of uneven development at the urban and regional scales (PECK and TICKELL, 2002). Local “growth coalitions” (LOGAN and MOLOTCH, 1987) have mobilised around various 
local competitiveness strategies, intensifying demands on the state (including its local and regional branches) to subsidise and promote urban growth in part also to induce regional economic development (COX, 1993; JESSOP, PECK and TICKELL, 1999). Yet such analyses of neo-liberal forms of urban and regional development seem unable to account for the emergence of a newer set of political demands on the part of firms and workers dependent on growth around new economic spaces; demands for additional investments in infrastructure, support services, housing, etc.; in other words, a "politics of collective consumption” (CASTELLS, 1977). Such demands have become commonplace in city-regions throughout North America and Europe, and are symptomatic of what we call a new territorial politics of collective provision.

The paper is organized as follows. Firstly, we argue that the new territorial politics of collective provision represents an important yet under-studied dynamic of governance and state intervention in maturing and growing new economic spaces. Second, we draw upon some concrete examples from recent research in the I-495 region in Greater Boston and the Cambridge city-region in the U.K. and identify some necessary and contingent features of this politics. Third, we outline a heuristic (causal model) of city-regional development showing a tendency to social-regulatory failure around neo-liberal growth spaces, which in turn has given rise to various territorial demands for additional collective provision. Fourth, we contextualize further aspects of this geography by returning to our examples. Here we reflect upon the specifics of the city-regional, national and global contexts. In conclusion, we suggest that empirical analysis of struggles around collective provision in mature and emerging high tech spaces in the U.S. and Europe offers a new entry point for theorising wider processes and politics of urban and regional development. 


\section{The New Territorial Politics of Collective Provision}

Despite the emergence of political demands and struggles around collective provision in the major city-regions of the global economy, the mainstream literature on new industrial spaces and clusters has not paid much attention to this aspect of regional economic development. Instead, a considerable amount of effort in urban and regional development theory is devoted to understanding the internal (e.g., inter-firm) dynamics of industrial districts and customised high tech spaces, or what can collectively be called new economic spaces (NES). ${ }^{1}$ One of the features of such spaces is a propensity to attract and grow various enterprises specialising in the information and communications technologies, biotechnology and other sectors of the knowledge economy, as well as supporting cultural economies, housing and retail developments, transportation, and financial services. Typically, NES occupy suburban locations in globally-connected city-regions, albeit there might be corresponding if not competing, strategies for attracting such developments back into the central city.

Thanks to the work of urban and regional scholars, including inter alia GRAY et al. (1996), HARRISON (1992), MASSEY et al. (1992), SCOTT (1988; 2001), and MORGAN and SAYER (1988), we now know much more about important aspects of the internal production dynamics of the spatial growth hotspots of the global new economy. Nonetheless, this knowledge has arguably come at the expense of corresponding appreciation of some of the fiscal, governance and regulatory problems around collective provision that often characterize these mature and emerging centres of high tech production (SAXENIAN, 1989; JONAS, 1996a; 1996b; LEIBOVITZ, 2003). Typical problems include the under-provision of workforce housing, customised infrastructure (water, sewerage, transport, electricity, etc.), sites for new 
development, parks and open space, schools offering relevant qualifications, customised training facilities, day care, healthcare, and so forth. Some firms provide these services and community facilities as an integral part of their labour control strategies (JONAS, 1996a); but many do not and turn to local public sector institutions to address a lack of local provision of those goods and services seen as necessary for new economy sectors (NEVAREZ, 2003).

Collective action is necessary to address the infrastructural and service deficits facing NES but the question is whether or not the state is involved. Assuming it is, precisely which territorial branches of the state are implicated is open to struggle and strategic action on the part of a variety of locally dependent interests (COX and MAIR, 1988; COX and JONAS, 1993). Given a proclivity for the state to pursue neoliberal economic policies (TICKELL and PECK, 2002) there is pressure on local and regional state capacities to follow suit and drive down location-specific costs. In this context, demands for additional investments in infrastructure and housing appear to work against the grain, not least in terms of bucking a trend towards greater interterritorial competition in economic development policy (see MALECKI, 2004).

Although the many small-to-medium sized firms that comprise the new economy might individually not place huge additional investment demands on the state and its territorial branches, the spatial clustering and growth of firms, workers and a whole host of support activities and services around cities and regions does generate such demands (cf. SAXENIAN, 1994). In fact, NES-dependent firms operating in different local jurisdictions across the same city-region might place competing demands on the same collectively-provided urban and regional infrastructure and services. Political decisions have to be made about which new expenditures and demands across a city-region are to be prioritised, and how to fund 
these collectively through various new structural and territorial arrangements in urban and regional government (PIVEN and FRIEDLAND, 1984).

By the same token, a nation state interested in supporting a particular NES will want to target that city-region for extra public investments in infrastructure and services in the hope it can back a likely winner in the international competition to generate jobs, wealth and taxes. The resulting extra collective-provision demands that are imposed on state fiscal capacities around the one city-region must be weighed against the corresponding underinvestment in services and infrastructure across the other city-regions of a state’s territory.

Although access to low-cost infrastructure and services has always been important to urban and regional development, conventional explanations for the development of NES have had surprisingly little to say about the new territorial politics of collective provision. It is generally assumed (rather than being subject to empirical scrutiny) that firms and investors operating in NES automatically benefit from the kinds of localised external transaction costs and positive social and environmental externalities that typify the competitive local industrial milieu. By implication, it is also assumed that local and regional territorial branches of the state responsible for providing infrastructure and services to NES are aware of the importance of quality above that of cost. Therefore they avoid internalising the sorts of transaction costs and political demands that are often associated with other "less productive”, “older” or "less entrepreneurial” firms and sectors, not just within the same city-region but also presumably other city-regions in a state’s territory.

Nevertheless, theories of the economics of public service provision and collective consumption have recognized that under certain circumstances territorial competition promotes service-delivery efficiencies (TIEBOUT, 1956; BISH, 1971). 
Such theories predict that mobile investments, jobs and people are always likely to relocate to local jurisdictions that are able to respond to match local service provision levels to local quality of life demands. Such demands, it is argued, reveal income, class and sector-specific preferences (TIEBOUT, 1956). One might infer that the new infrastructural and service demands to be found in NES are simply expressing new sector-specific preferences. Yet as we now argue, there are a range of other political and economic dimensions of the "quality of life" matrix that ought to be factored into the local spatial development milieu. We need to revise, rethink and update existing approaches to the public economy of city-regions.

\section{Approaching the New Territorial Politics of Collective Provision}

It has long been recognised that capitalist growth puts demands on a city or region's physical and social infrastructure in terms of land scarcity, traffic congestion, house price inflation, and demands on the local tax base (HARVEY, 1985: 125-164). Growth induces urban agglomeration effects that can benefit local producers and consumers; but as we have argued urban and regional development in turn generates externalities and costs for workers and firms. In today's global city-regional economies, it appears that there is an endemic failure to internalise the economic, social and environmental costs of new forms of growth due largely to the lack of development of corresponding state and governance capacities (SCOTT, 2001). However, this is not to say that businesses organisations, trades unions, community and citizen groups, housing associations, and transportation interests are not politically active. On the contrary, across cities, suburbs and entire regions demands on behalf of local business interests are expressed almost on a daily basis for the 
enhancement of local and regional infrastructural and governance capacities (JONAS and PINCETL, 2006).

In focussing upon how cities and regions can compete to attract new economic activity, conventional theories often fail to acknowledge the ongoing importance of demands for collective provision to the economic development of NES. ${ }^{2}$ Indeed, one might anticipate that one longer-term effect of supply-side forms of spatial development has been the accumulation of a structural-regulatory deficit in meeting or regulating demand around collective provision at particular locations and sites of growth across city-regions.

While some researchers have studied the new forms of infrastructure to be found in city-regions (GRAHAM and MARVIN, 2001), the mainstream literature continues to prioritise the new generation of supply-side models of territorial economic governance, especially those that reduce the costs of doing business locally. These include various forms of competitive regionalism in the U.S. (CLARKE and GAILE, 1998; JONAS and WARD, 2002), and so-called "soft” regionalism in Europe (MORGAN, 1997), albeit the new regionalist orthodoxy currently sweeping spatial development theory has not been without its critics (LOVERING, 1999; MACLEOD, 2001). In light of these growing criticisms, there seems to be a good case for situating certain aspects of research on NES growth trajectories within a more abstract critical analysis of the role of the state and collective provision (HARRISON, 2007; WARD and JONAS, 2004).

By the same token, insofar as there has been any attention paid to the social needs and demands of the knowledge workforce (CRANG and MARTIN, 1991; GRAY et al., 1996), much of this remains couched in terms of supply-side discourse and rhetoric. To take one influential example, FLORIDA (2002) suggests that the 
long-term success of NES depends on the continuing attractiveness of city-regions to workers with requisite skills and creative talents. Implicit in this argument is the view that quality of life, social mix, and the social integration of workers are central to the supply-side dynamics underpinning city-regional competitiveness. Although the creative-class thesis has been a focus of some critical analysis in the literature (NEVAREZ, 2003; McCANN, 2007), the basis of such critique has evidently not been founded upon its chronic neglect of collective provision, i.e. aspects of the demand-side cost considerations shaping class relations and local growth politics in capitalist growth regions.

All-in-all, we know surprisingly little in terms of the range and variety of growth-related demands of NES; nor about the new territorial politics of collective provision across any given city-region. Such knowledge might not only shed light on the changing geography of the state under neo-liberalism but also invite consideration of the extent to which new state geographies reflect new and alternative political and economic rationalities (e.g., neo-Keynesian, the “Third Way,” liberal progressive, environmental and social sustainability, ecological modernisation, etc.). To be sure, the intensity of conflict around a given city-region might well reflect regulatory failure in those modes of state social provision constructed under neo-liberal rules and conditions. So examining different geographies of neo-liberalism is certainly part of the story (TICKELL and PECK, 2002); but only a part. In addition, a fairly detailed empirical knowledge of local and regional state geographies operating under historic or new and different development pressures and modes of social regulation (e.g., developmental, postcolonial, regionalist, federalist, etc. modes) might equally be required. Such differences in local and regional geographies of the state are important in mediating between the concrete spatial interests of NES-dependent firms and 
workers, on the one hand, and the wider (national or global) politics of collective provision, on the other (COX, 2002).

We now briefly demonstrate the changing nature of demands for collective provision and accompanying state territorial adjustments by reference to two examples taken from two quite different contexts: Boston in the USA; and Cambridge in the UK. These examples are presented in a somewhat schematic fashion in order to illustrate our conceptual approach. Suffice it to say that detailed research is underway in both places, as well as in a wider sample of NES, which we hope will lend further support to our claim that the new territorial politics of collective provision is an important yet under-researched feature of local and regional economic development in NES.

Geographies of Collective Provision in New Economic Spaces in the USA and Europe

Boston's high tech-driven city-regional growth: Crisis of housing affordability and finding revenue for regional infrastructure renewal

Alongside Silicon Valley in California, the Boston metropolitan area has been cited in various studies as an example of a successful high tech growth city-region in the U.S. For example, the 2007 State New Economy Index ranked Massachusetts ${ }^{3}$ top of the league table of U.S. States according to its measure of economic development (ATKINSON and CORREA, 2007). This measure takes into account the number of high value-added jobs created and retained rather than traditional measures of economic development (e.g., number of corporate branch-plant relocations or “smokestack chasing”). As the largest city-region in Massachusetts, Boston has 
obviously played a key role in the development of the new economy across the State. Early growth around computer and defence-related sectors in the 1960s and 1970s has been succeeded by new forms of growth around ICT, biotech and financial services. A recent study by YU (2003) ranks Boston fourth after Chicago, Washington DC, and the Silicon Valley, respectively, in terms of the US metropolitan area with the highest total of "high tech" jobs.

Notwithstanding the material significance of the knowledge economy, Boston's economy remains quite diversified relative to that of its "competitors" (i.e., other U.S. States or even new international growth centres like Dublin in Ireland). The basis for this diversity lies in the retention of some traditional jobs in manufacturing industry as well as the growth of retail and financial services. Some new growth has happened along the Route 128 suburban ring immediately surrounding the City of Boston but more importantly further west along the I-495 corridor and extending out to the City of Worcester and neighbouring towns and suburbs. Since the 1980s, many of these outer-urban communities have seen significant transformations in the local politics of economic development: from local forms of "corporate welfare” to the current emphasis on attracting new service and technology industries, many of which have since come under external (foreign) ownership (JONAS, 1992).

Although new forms of high tech and related employment growth are spread throughout the Boston city-region, our present focus is the 32 towns and suburbs along the I-495 corridor (Figure 1). As we will argue, due to the strong presence of NES interests this sub-region of the larger Boston metropolitan area has begun to develop a separate regional economic and political identity. Significantly, this development is accompanied not so much by attempts to attract capital and 
investment to the region (i.e., territorial competition) but local and regional demands for collective provision. An important regional player in managing these new demands is the 495/MetroWest Corridor Partnership, a non-profit economic development organisation which was established in 2003 to represent the interests of firms, local chambers of commerce and the local government jurisdictions in this part of the Boston city-region. ${ }^{4}$

\section{*** Figure 1 about here ***}

In terms of the wider context, NES-related demands for collective provision in the I-495 region have come in the wake of attempts by the State to promote the more usual array of supply-side forms of economic development. In this respect, Massachusetts’ fiscal crisis of 1990-91 was represented as especially damaging to the competitiveness of established high tech interests along the Route 128 corridor, and accelerated the structural decline in manufacturing jobs State-wide. In response to this particular crisis, reform-minded business groups searched for new fiscal and regulatory supply-side solutions to what they saw as various economic development challenges. The result was a move to promote a stronger competitiveness agenda across the State's economic regions in part to overcome perceived failures and weaknesses in new economy and financial services sector based in Boston (JONAS, 1996b). In Boston, there had been a particular emphasis on supply-side economic development projects around improving regional transport infrastructure (e.g., the socalled "Big Dig” tunnel linking the suburbs, airport and downtown) as well as the promotion of various mega-project developments like new sports stadia and regional shopping and entertainment centres (HORAN and JONAS, 1998). These projects might have strengthened the economy of downtown Boston but arguably did not benefit the more deprived inner-urban communities; nor for that matter did they 
address the spatial needs of established and newer manufacturing centres in the outer parts of the city-region.

Some sectors and firms operating in the I-495 region continue to struggle to compete in what is still seen as an unfriendly regional business climate. Yet from an economic development perspective the primary concern is how to manage growth rather than how to devise a competitive tax and regulatory regime that supports Boston-based sectors or manufacturing State-wide, albeit it could be agued that fortunes of the two are inter-related. For local interests in NES in outer Boston in particular, two significant areas of economic development concern are promoting housing affordability for entry-level knowledge and service-sector workers and provision of high quality infrastructure for locally-based firms.

In the case of addressing problems of workforce housing affordability, the issue is often constructed as one of supply but that this, in turn, is underpinned by growth-related demands. The latter tend to be specific to the local jurisdictions served by NES. In terms of the politics, there is a particular concern that addressing demands for workforce housing is not to be confused with the provision of social housing across the State more generally since in any case "affordability" is uneven between local political jurisdictions. Here, the fragmentation of the city-region into independent self-governing municipalities and towns is seen to be part of the problem rather than the solution:

Massachusetts housing activist: $\stackrel{-\rho}{\underline{\underline{E}}}$ first thing [is] supply. Massachusetts is a very high- barrier-to-entry housing market. Among other things, we have 351 cities and towns, each of which is a separate political jurisdiction. So that each of those cities and towns sets its own zoning, sets its own design standards. And there is a huge amount of what we call here Not-In-My-Back- 
Yardism (NIMBYism) going on, so that it is very, very difficult to produce new housing. Arguably juxtapositioned [sic.] against that, we have the longest and most productive history in the country of producing subsidized housing for low income people. Part of that is because when those programs began in the late 1960s and 1970s we had a cadre of real estate developers in Boston, who, for whatever reason, were interesting in taking advantage of government programs, and we had an existing housing stock which was the oldest in the country [and in need of] rehabilitation. (Interview, September, 2007, our insert.)

In terms of unlocking these barriers to supply in suburban areas, attention is focussed upon State laws and regional growth management policies. A particular focus of ongoing conflict is Chapter 40B. ${ }^{5}$ First enacted in 1969, Chapter 40B is the State of Massachusetts’ so-called “anti-snob” or “affordable housing” law, which requires suburban municipalities to relax zoning and enable the development of higher density affordable single-family housing. This law over-rides "local control” in regards to land use authority, enables municipalities to produce more housing on smaller lots than the more typical half acre and single acre lots, and thereby promotes housing affordability. In the I-495 region, it has been championed by housing developers and activists alike as a way of resolving a backlog of housing construction in suburban areas to meet NES-driven demands.

However, housing provision is not the only growth-related issue in the I-495 region. New house-build in outer suburban areas creates a demand for services and schools on the part of the middle classes and those seeking employment in new economy sectors. In Massachusetts, the difficulty of meeting these demands locally is compounded by Proposition 2⿺辶⿸厃㔾 , which restricts increases in local property taxes to a 
$2.5 \%$ annual increase regardless of the assessed market value of property. Suburbs facing revenue pressures might once have opposed the construction of affordable housing at the lower end of the market (e.g., due to fears of promoting "racial turnover"). Today, however, such opposition is not so much an issue to be constructed around "race" -- since, for example, Boston area public schools are no longer under a court-ordered program of desegregation -- but is framed quite explicitly in class terms. The argument is that restrictions on new housing development make it difficult for entry-level workers to afford housing close to work. Here NES growth interests have been able to connect problems of regional economic development to a class politics of collective provision.

In this, there is an opportunity to construct a powerful counter argument to those who might oppose the construction of so-called affordable housing in established suburbs. Credence can be given to claims to the effect that building more housing in the suburbs to meet employers' demands redistributes wealth more equitably, regardless of whether property values are rising or falling (the latter has become a more acceptable part of the new territorial discourse in light of the "crisis" in subprime mortgage lending). This is because workers will not have to devote such a significant proportion of their income to the costs of commuting if homes can be built closer to work. For firms and their allies in the house-building sector, recasting the politics of collective provision as a problem of regional (in)equity offers a powerful weapon in brokering conflict with, on the one hand, State and regional organisations that want stronger regulation and growth management and, on the other, taxpayers and existing homeowners interested in repealing Chapter 40B. ${ }^{6}$

A second area where collective provision becomes important in the politics of local and regional development in Massachusetts is the debate about infrastructure 
renewal. This has been festering for a number of years but in our research we find that it has intensified into a full-scale regional "infrastructure crisis" which, according to Boston-based business organisations and transportation experts, can be costed at $\$ 20$ billion as the estimated deficit State-wide in funding for infrastructure renewal. Although finding revenue for future investment in infrastructure is a concern for taxpayers, transport providers and business and industry organisations across the State (and indeed the U.S.), from the standpoint of I-495 firms the issues are more concrete. The debate is much more focussed around reducing travel costs for high tech and service firms and workers within the region. The strategy is to improve connections between towns and suburbs along the I-495 and adjoining local routes, along with further improvements to regional transport so that workers can spend less time and money on commuting to jobs.

The challenge is how to connect these place-specific needs to wider demands across the city-region for transit-orientated developments, affordable housing and infrastructural renewal. Access to Federal funding for infrastructure renewal has become a new battleground, but in the past the high tech sector in Boston has discouraged any debate about raising taxes to fund infrastructure and services (JONAS, 1996b). The result is a vibrant new territorial politics of infrastructure renewal, with arguments now constructed around, for example, how much Massachusetts commuters and taxpayers pay in the form of taxes on the sale of fuel compared to those in other States, and how much the State receives in turn in Federal transportation dollars.

Subsumed within this is another economic development discourse specific to NES interests in the I-495 region. This involves the relationship between -- or politics of -- funding infrastructural renewal in the suburbs, on the one hand, and building co- 
operation between various regional transport and planning organisations involved in delivery, on the other. Here it could be argued that recent Federal support for investments such as the infamous "Big Dig” project have tended to privilege links between the city's airport, the inner suburbs and downtown Boston and its financial sector firms. From the standpoint of suburban high tech interests, the solution to the “infrastructure crisis" is not a question of making Boston per se more attractive to knowledge workers or the creative class (FLORIDA, 2002). Nor is it necessarily a question of enabling Massachusetts to compete with other States through tax policy. Rather it is a more concrete set of concerns; new policies and state territorial structures are needed to build affordable and workforce housing, address local infrastructural issues, and retain and attract the workforce to meet a growing demand locally for entry-level high tech and service jobs specifically in suburban spaces. Promoting supply-side economic development policies and attracting firms and knowledge workers to the State or the city distracts attention from these more localised growth problems. In other words, there are likely to be different spatial interests at stake in meeting the collective-provision demands of NES. Yet such conflicts-of-interest (e.g., among business factions) are often not taken into consideration, especially in neo-classical and neo-institutional approaches to territorial competition.

\section{The Cambridge Phenomenon and "Invest in Success"}

A growing emphasis on meeting demands for collective provision also shapes struggles around new centres of NES development in the UK's relatively prosperous and growing South East region, particularly around the Peterborough-CambridgeStansted M11 Corridor (or what might be called the Cambridge “city-region”). The 
rapid growth of the Cambridge economy in the 1990s -- what was known as The Cambridge Phenomenon -- led to some heated debates around collective provision. The issues here were the provision of sites to allow local firms to expand, new housing for the workforce, especially housing affordable to so-called "key workers" (see RACO, 2008), basic infrastructure and other support services. The debates have intensified as the Phenomenon moves into what has been described in a consultancy report as a "second phase” of growth (PACEC, 2003). As with the Boston example discussed above, the main point we want to make here is that the politics of collective provision in Cambridge has become inseparable from the politics of economic development. However, there are some important differences in the way this politics works through the specific geographies and regulatory assemblages of the U.K. state.

From the standpoint of interests speaking for high tech industries, the university and service firms which talked up a Cambridge "growth crisis" in the 1990s and early 2000s helped to focus local state attention around a lack of governance capacity around collective provision (WHILE, JONAS and GIBBS, 2004a). These governance and regulatory failures involved not just constraints within existing local and national planning frameworks (e.g., green belt policy) and local government structures (e.g., state spending restrictions on local government) but also a structural crisis of under-provision in regard to housing and supporting infrastructure. The argument has been that inward investors and entrepreneurs need to be located close to the geographic centre of the Phenomenon in order to access the cluster of research parks, support services and infrastructure found there. In this context, various local high tech interests and their allies in local government have begun to talk of the need to "invest in success" (GCP, 2001), or risk losing investment to rival international NES destinations. 
Moreover, it is in this context that "place entrepreneurs” (LOGAN and MOLOTCH, 1987) have made the not-unconvincing argument that "Cambridge” suffers from a financial as well as infrastructural deficit, and that the crisis of underprovision remains a threat to the city-region's economic sustainability on a European scale. The deficit refers to apparent shortfalls in state expenditures on infrastructure, transport, water, sewerage, police, health and education in relation to what Cambridge and its region contributes through taxes on economic growth. Indeed, a focus of ongoing struggle has been the Standard Spending Assessment (SSA), which is a negotiated mechanism for allocating central government fiscal support to counties based on various demographic and economic factors and current service needs, and accounts for the majority of locally controlled finance. The issue here is the creation of a funding mechanism for capital expenditures on infrastructure and key services so as to accommodate future growth in the sub-region, something which the SSA formula for Cambridgeshire as a whole apparently does not take into consideration:

Andy Jonas: So [there] is the argument about the infrastructure deficit. So what's the politics of that?

Cambridgeshire County Official: The SSA [standard spending assessment] argument is about basic core services, care of the elderly, pupil-teacher rations ... We've got an extremely low SSA, particularly compared with our immediate neighbours because there are area cost adjustments. So there is a feeling that our core services are under-funded. But that is the recurrent spending. This debate is about capital and investment; the two of course are interrelated, but here it is about the investment needed. In actual fact, we've always been a revenue-poor County because of the SSA (we've been not rich, but moderate as a County Council), but what we've never seen is any large-scale investment to go with 
growth...It's a governance issue, in this mishmash where there was no leadership from anywhere because everyone’s got diffused responsibilities, who’s taking responsibility for making this $£ 2 b n$. happen, who’s taking responsibility for making these 70,000 houses happen, who’s taking responsibility for quality, who’s taking responsibility for making sure it is sustainable?

Aidan While: It's interesting because the story could be seen as being central government unblocking the city, but it seems to be more about local responses.

County Official: Exactly, yes. What helped a great deal on the way is [the regional] Government Office, and they have been absolutely super - they've been totally tuned not only to the needs of the area but also to the sensitivities of national politics, so they’ve known when to intervene, how to intervene. Without that we wouldn’t have got very far (Interview, August, 2002, our insertions).

So even in the context of a more centralised territorial structure such as the U.K. state, there is an emergent politics of collective provision. Crucially, in this case it is a politics that has been selectively constructed as a problem of territorial scale. In order for Cambridge to continue to grow and compete as a NES, it is necessary to construct arguments in territorial-political terms that are fiscally advantageous. One solution is to exploit existing social class and consumption sector-driven fiscal disparities across a wider territory -- in this case the entire county -- in order to make the political case for extra investment for the Cambridge “city-region”.

We suspect the situation in Cambridge where new connections have been made -- albeit selectively and strategically in terms of class, territory and scale -between the politics of collective provision and local and regional development is not unusual for mature and emerging high tech regions. However, there are some important differences between our two examples. In Boston, the debates about 


\section{Approaching the New Territorial Politics of Collective Provision}

As our examples show, addressing the growth needs of NES involves sustaining and enhancing the existing and future levels of provision of infrastructure and services. We call this the new territorial politics of collective provision, and it involves inter alia demands from: locally dependent firms for collective provision of infrastructure (water, sewerage, transport, etc.) and other services (e.g., developable land); workers of all different social classes and incomes (i.e. not just elite knowledge workers) for social consumption in the living place (e.g., affordable housing, good schools, environmental amenities, etc.); and from the local and regional public authorities (e.g., for additional local taxes, grants, voter-approved bond issues, and revenue from higher levels of government). These demands have different implications for how economic development institutions manage problems of 
collective provision in their service territories. Moreover, the geography of the state is important in shaping how these demands map concretely onto space.

We now are in a better position to propose a heuristic (or conceptual model) of the role of spaces of collective provision in the politics of global city-regional development (Figure 2). We start out by noting the necessary possibility for the existence of spaces of under-provision. These spaces can be defined as those cityregional economies where there is a failure to generate the infrastructures and services seen as necessary for sustaining NES. These might include workforce housing, hard and soft infrastructure, transportation, land use and related services. Identifying spaces of under-provision (and related demands for extra-provision) could be associated with the corresponding over-development of local firm-level production capacities, or overzealous national government policies to establish sites for NES without supporting fiscal resources. Or it could simply be a locally-expressed need for extra provision on top of initial investments so as to keep up with the competition in the same city-region or elsewhere.

\section{$* * *$ Figure 2 about here $* * *$}

NES exhibiting such political-regulatory “failures” will have a sudden proliferation of state and non-state actors and agencies devoted to addressing the problem of lack of provision (or social regulation of) basic infrastructure. To put this somewhat differently, the development of what has been described as "institutional thickness” (see, e.g., AMIN, 1994) around spaces of collective provision could be as much a sign of structural-institutional weaknesses as it is of economic success.

Underpinning all of this is the need for growth interests to find alliances, build political support and develop new governance capacities around specific territories. This may be a case of business interests selecting strategic allies in local civil society 
or the local state, or drawing in support from other social classes, around existing state territorial structures, and constructing in the process new structures -- for example, by building the economic development case for a new civic regionalism (JONAS and PINCETL, 2006). Conversely it might be the case of elected politicians, planners, policymakers or local residents taking the lead in forging a governance agenda on the basis of environmental and quality-of-life concerns (e.g., promoting sustainable forms of transport). The possibilities are many and varied, and give rise to all sorts of hybrid state-market forms of collective provision and state territorial structures.

Here we are further reminded of arguments about the tendency or even the necessity in capitalism for alliances to form around particular territories (HARVEY, 1982). For Harvey, the incentive for building cross-class territorial alliances comes from the material threats posed by capital's inherent spatial mobility to various forms of immobility: those in particular pertaining to fixed investments in social and physical infrastructure. We can now augment this with the idea that territorial coalitions are formed in places (and around state territorial scales) in ways that aim to generate extra state and private infrastructural and service investment and jobs in the long term. So here the agenda is additional collective provision and the anticipated higher returns on future state investments in social consumption and provision As space relations alter in response to transport [and related infrastructural] investment, so do the relative fortunes of capitalists in different places. Some suffer devaluation of labour power, their fixed capital and consumption fund (housing, etc.) while others enjoy, temporarily at least, excess profits and upward revaluation of available means of production and consumption (HARVEY, 1982: 378, our insert and emphasis) 
One might further hypothesise that the case for additional fiscal or regulatory support for NES from the state becomes couched in terms of ideas of a moral space economy (see COX, 1999). This is important when the growth problems facing some NES are compared and contrasted to the fortunes of others, or when support for one city-region is required even when there are obvious deficits in state welfare and infrastructure provision at others. Here it is important to demonstrate that what might be seen as rational and equitable for one NES (because it has already proven its net national or regional social worth) is likewise good for others, whether these others are in the same city-region or beyond; in which case, the definition of scale, region and territory becomes more "stretched out” and "socially inclusive” (JONAS, 2006). It might further be necessary for those interests dependent on NES growth to anticipate counter-arguments (against further investment or state support) in moral spatial terms on the grounds that other interests likewise dependent on welfare and collective provision might be more deserving of state support. Here it is important for NES interests to incorporate -- albeit selectively and strategically -- contemporary discourses of social inclusion, regional equity and environmental sustainability so as to make the case. We believe that new social and environmental sustainability discourses are most likely to found in those city-regions where NES interests are able to identify a severe collective provision "crisis”. Crisis, in turn, shapes new forms of collective action, which reinforce, underpin or perhaps at times conflict with a politics of economic development constructed relentlessly around territorial competition.

\section{Some Additional Territorial Dimensions of the Politics of Collective Provision}

It is apparent from all of this that the management of the politics of collective provision in NES can pose immense organizational and legitimacy problems not just 
for firms but also the national state. Tensions centre upon maintaining circuits of investment in localised NES growth sectors (including provision of additional basic services and infrastructure) and managing problems of uneven development in the wider national territory (e.g. addressing housing affordability more generally across the state's territory). As our examples suggest, such problems are particularly acute in places with particular concentrations of new economic sectors (e.g., suburban areas of Boston or semi-rural areas around freestanding university cities like Cambridge) since in many respects these are often seen as already economically, fiscally and socially privileged spaces. The challenge is how to construct a politics of collective provision in terms that prompt the state (along with other agencies) to channel resources, investments and fiscal capacities to these places and away from other arguably equally deserving and under-serviced spaces. All of this suggests the importance of contextualizing our argument with respect to particular historical conditions and national social contexts, which we will now attempt.

\section{Collective provision and regulating the capital-labour relation}

First of all, there is a need to address the historically contingent form of the politics of collective provision in the overall process of social regulation in capitalism (AGLIETTA, 1979). By definition, NES are maturing or emerging spatial forms of capital accumulation, which in turn generate particular needs, struggles, conflicts, and demands around labour control (JONAS, 1996a). Collective provision is a factor here: firms must develop new infrastructural and service capacities and community facilities in order to integrate their workforces into the production system effectively and in a non-conflictual fashion. Given that the particular labour and infrastructure requirements of NES are not in the first instance met locally, crises of collective 
provision are likely to be instrumental to wider struggles around the social regulation of the capital-labour relation. Social regulatory issues likely to be displaced to the wider space economy include: maintaining wages and income levels attractive to workers in the knowledge economy; upgrading skills in these and related sectors; spatially integrating workers into the national production system; supporting and sustaining labour's consumption fund, etc. Some issues will remain localised, such as: seeking further improvements in conditions in the living space; maintaining the quality of infrastructure and the local environment (parks, recreation, and open space); facilitating the supply of labour through housing, transport, schools, health provision, and so on; and more generally meeting the demands of local firms, residents and workers for socially adequate or "high quality” services.

By definition, these social regulatory and labour control considerations have only recently become issues characteristic of NES. So it is not surprising that the corresponding regulatory structures are weakly developed. It takes time for firms, business and industry groups and relevant actors to respond to the territorial challenges of new forms of growth and development; in fact they can be quite hostile to state intervention initially. For instance, high tech industry in suburban Boston has in the past operated as a free-rider when it came to matters of collective provision especially at the State-level (SAXENIAN, 1989). The sector was at best indifferent if not in fact outspoken and generally anti-government, anti-taxation and anti-regulation (i.e., its political rhetoric was broadly in tune with neo-liberal supply-side national economic policy). It was left to other reformist manufacturing and business organisations based around Boston to engage in economic development policy (JONAS, 1996b). This attitude has changed 
Andy Jonas: Thinking about economic development, how would you characterise how that has changed in the last few years in the Massachusetts' context? Are you talking about economic development from the standpoint of a cost factor or quality of life?

Massachusetts business organisation representative: I think is a change over the last decade or more. Clearly, the competition nationally and internationally has probably been the biggest paradigm shift. If you take a look a decade or so ago, it was pretty much that businesses had to be in Boston... Not quite so simple, but in essence it was a little bit more of case where we don't have to do as much because there is so much of a demand coming in here not to need to create incentives and such like that. Well, clearly that's not totally true but that was the attitude. That attitude sort of collapsed, probably around 1990 when we had a recession here; that was certainly a breaking point... that was for a lot of us the warning sign that we have a serious problem, and that if we don't start to become much more competitive, stacking ourselves up head-to-head with some of these other States coming here on a daily basis recruiting companies that have 50 more employees to come to their State with a lot of incentives. The interesting thing is of course that financial incentives are part of the deal closer. Companies don't move just because of financial incentives but they will move because of the human resources or the other kind of resources they need... but if you're looking for high quality talent [Boston] is a place to be, but now there are other places to be, and we have to compete against that. So, the competition nationally and internationally has become the real kick-off for us to try to look critically at what we are doing. (Interview, September, 2007, our insert.) 


\section{New spaces of governance around collective provision: the politics of city- regionalism}

To the extent that the new territorial politics of collective provision is becoming a driver of NES growth, our arguments also speak to recent work on new geographies of city-region governance. This is more than a case of building local economic development networks amongst local firms but crucially also alliances with various city and regional authorities and community organisations involved in mediating interests dependent on NES; interests in the labour market, land use planning, housing, infrastructure, healthcare and perhaps even welfare. If there is an ongoing reliance upon supply-side measures (new taxing authorities, special purpose districts, and the like), the political case for these still has to be made and this increasingly requires constructing new partnerships and coalitions around addressing deficits in infrastructure and collective provision across the wider city-region.

In both of our examples the politics of collective provision has resulted in new alliances and institutional developments and a deepening of the division of labour across the city-region. ${ }^{7}$ At the heart of this is a politics of organising an appropriate or functional (that is, for capital) scalar division of labour in the state (COX and MAIR, 1991). In a more centralised state like the U.K., responsibility for economic development has been partially devolved to the regional and sub-regional levels, as also to some extent has responsibility for delivery of services. Our Cambridge example also reveals how the politics of collective provision can be up-scaled geographically within the city-region in order to connect NES needs to wider demands for welfare provision in the territorial state.

In a Federal state like the U.S., there are attempts by metropolitan and regional organisations to draw down responsibilities and powers from State and Federal 
government. In the suburbs of Boston, there might be scope for local fiscal autonomy but the parochialism of local government creates problems; hence the interest in creating new forms of regional governance appropriate for NES development. Despite the growing strength of the New Regionalism, there is little evidence even in a paradigmatic NES such as the I-495 region in Greater Boston that what has resulted amounts to a "structurally coherent" city-regional form of governance. Instead, cityregions like Greater Boston are becoming territorially fragmented in new and complex ways. At the same time, fiscal relations and struggles around Federal, State, regional and local territorial structures have become if anything more fluid, contested and complicated.

What seems to be a thread common to both our examples is the increasingly central role of the politics of collective provision in economic development. Such a politics makes conditions of economic success or failure of NES as much a matter of struggles around state geography as one of the (lack of) development of self-contained regulatory capacities.

\section{Collective provision and the politics of social globalization}

So far we have concentrated on institutions and regulatory processes specific to two NES, one in the U.S. and the other in the U.K.. In that respect, we could be accused by the likes of WOOD and VALLER (2004) of an obsession with the form rather than substance of local institutionalism. Indeed, it might even be argued that our examples offer further evidence in support of what PECK and TICKELL (2002) call a shift from the "roll-back" phase of laissez-faire deregulation in the 1980s to a new and softer phase of "roll-out" neo-liberalism designed to account for some of the earlier social contradictions and crisis tendencies of unfettered market-based 
economic deregulation. At one level we would not disagree with such criticisms and observations. Yet are we talking about new spatial forms of neo-liberalism or perhaps instead altogether different forms? In other words, are we talking about radically new territorial-political rationalities and forms of collective action around NES? It seems that our examples point to counter-tendencies in the neo-liberal project and, indeed, can perhaps be marshalled to dispute some assumptions upon which claims are made about the politics of space as being colonised by spaces of neo-liberalism to the exclusion of all other territorial rationalities.

We feel that certain representations of the current regulatory transition as dominated by supply-side policy frameworks that seem to fit an over-arching neoliberal spatial hegemony could benefit from a more explicit spatialisation. There is, for instance, a relation between the place-specific politics of collective provision and the wider “politics of globalisation” (COX, 1993). The politics of globalisation involve a dominant shift in spatial politics (i.e., demands on the state) towards the supply-side and competing on an international stage for globally mobile capital; a shift that privileges, in particular, multinational capitals and nation states, but also implicates urban and regional players including property developers and local financial firms. ${ }^{8}$ Yet our argument is that various new challenges (not so much to the neo-liberal project as to the profits of local firms and the incomes of workers) are appearing from within the very spaces that appear to have benefited most from globalisation. The further development of NES requires interventionist policies despite globalisation. We might call demands for such policies the new territorial politics of social globalisation. An example of the politics of social globalisation is the "Third Way" model of territorial development promoted by advocates of a new “social” Europe. $\stackrel{-\rho}{\underline{E}}$ model “...counters the adverse effects that globalization can 
have on inequality and the low skilled, but at the same time is open to the world and invests in the future” (LIDDLE, 2006: 291).

Consider in this light the origins of new forms of state intervention around collective provision in the growth areas of Europe. In the U.K., market-led deregulation has exposed contradictions in the neo-liberal project and has been come to be opposed or questioned at least by the very geographic interests it was designed to support: those of financial sector and new economy firms in London and the South East. What “New Labour” (the Labour Government under former Prime Minister (P.M.) Tony Blair and the current P.M., Gordon Brown) has in part been about has been addressing the social under-regulation of the capital-labour relation: investing in housing and infrastructure; providing income support; investing in communities; and the like. Here the Labour Government has been quite explicit about the necessity of the state's role in managing in the politics of collective provision. Of course, private interests remain at the heart of this (e.g., encouraging investment in the housing market and relying upon state-regulated private finance initiatives) so finding a right balance between state and market has not always been easy. If the "Thatcher years" of social deregulation were built around driving down the social costs of labour and privatising collective provision, in the new political economy this is not enough (PECK and TICKELL, 1995).

In the national political calculus around sustaining collective provision places like Cambridge now become important for driving forward the U.K. state's ongoing commitment to the new European social economy, and for maintaining its competitive advantage internationally. This means, not just collaborating with places in Western Europe like Helsinki, Stockholm, Munich, Barcelona, or Sophia Antipolis, but also with NES elsewhere. New Labour has an important weapon for securing 
support for its wider social project from NES interests that have not always been sympathetic to growth. The weapon is housing on a mass scale, and in particular to address claims of shortages resulting from the so-called "not-in-my-back-yard" (N.I.M.B.Y.) attitudes of (e.g., Conservative Party-controlled) district local authorities and residents. This apparently is dampening the supply of "key workers” (e.g., workers in sectors such as education, health, the police and the like) crucial to economic success (RACO, 2008). Thus the national political significance of the crisis of under-provision in Cambridge is not that (as supply-siders or adherents to the creative class thesis might suggest) "local politics” interferes with the attractiveness of the place for very highly-skilled or elite workers, place entrepreneurs, and the like, and that this threatens its "success" or "creativity". Rather it is the lack of state intervention around collective provision that diminishes the supply of all categories and social classes of workers by making it socially impossible for low and middle income households to move to or live in these places. Not surprisingly, questions of “quality of life” are couched increasingly in concrete terms that resonate with national priorities: for example, optimizing the "social mix" in new house build, increasing the social housing stock, and balancing new growth against environmental issues like water shortages and loss of open space. ${ }^{9}$

In the Boston example, the presence of a new territorial politics of social globalisation is not so obvious. Nonetheless long-standing national social tensions do appear to underpin important divisions around the more contentious local growth issues like funding infrastructure renewal, overcoming the legacy of racial and class segregation in the suburbs, attempting to reduce lower and middle class dependence on automobiles, and switching to carbon-neutral investments in alternative forms transport (e.g. commuter rail). In particular, where access to Federal funding is at 
stake struggles around the spatial politics of mobility and immobility associated with various forms of NES development are becoming more commonplace. This could have important implications for examining the new ways in which business groups find political allies across the city-region, both in the public sector and in civil society (cf. HENDERSON, 2004). ${ }^{10}$

\section{Conclusions}

This paper has attempted to draw out some possible links and connections between urban and regional development and what we have called the new territorial politics of collective provision. In terms of its contribution to conceptualizing urban and regional development in the U.S., the paper has three points to make. First, recent institutional approaches to local economic development have afforded causal priority to the governance structures and agents that mediate between local sites of investment and wider geographies of capital mobility. Notably there has been the important work on growth coalitions (LOGAN and MOLOTCH, 1987) and post-federal local entrepreneurialism (CLARKE and GAILE, 1998); work which by-and-large has emphasised the contribution of public-private partnerships and regional governance in mediating supply-side economic development. Without dwelling on details, we can say that this work has (to the extent that it has been interested in collective provision) by-and-large emphasised the role of the state as one of facilitator or steering agent, serving as the local broker and risk-taker in meeting supply-side needs and bankrolling the assets of hyper-mobile capital (cf. JESSOP, PECK and TICKELL, 1999). The clear beneficiary in all of this is capital, whether it is in the form of industrial clusters, firms and development interests dependent on new economy spaces, or prospective inward investors; in other words, localised capitals operating in 
global markets and networks. But not so much other agents, especially local states, social movements, workers, lower and middle class consumers, and of course those seeking housing and work, the unemployed, underemployed, and the servicedependent.

Second, if there has been some attention to the geographic form of the state in recent urban and regional development theory, it is often seen as derivative of wider capitalist forces of economic growth and the neo-liberal project rather than a product of local demands for collective provision. Here the direction of causality works not simply "downwards" from the international and national levels through the territorial hierarchies and structures of the state to the city-regional level (e.g., to putative cityregional state formations) but also laterally across the economic landscape, perhaps as networks, flows and externally-orientated forms of governance. These bind NES and city-regions into wider networks and regulatory frameworks, albeit in a spatially uneven fashion. What little space there is in all of this for understanding the contractions and regulatory tensions within and around NES -- for the "give-and-take" of agency, politics and conflict -- is broadly subsumed within a discourse of the hegemonic needs of global capital and the banal institutional landscapes created by neo-liberal regulatory forms. A clearer sense of contestation and conflict around fiscal flows and investments in social and physical infrastructure across a city-region is fast being eviscerated from the intellectual landscape of urban and regional development. It seems as if NES appear magically, utterly detached from their formative and contested city-regional and national social formations.

Third, and by extension, there is a danger that knowledge of how the needs of workers and households working and living around NES are negotiated and managed on a day-to-day basis is analytically shoved to one side (WARD and JONAS, 2004). 
Likewise, knowledge of the attendant social and gender divisions around consumption sectors and income groups is not always central to the analysis of city-regional development dynamics (JARVIS, 2007). Yet our argument is that NES interests cannot be so easily detached from other spaces of welfare and social provision.

Are these surprising conclusions? It would seem they should not be. After all, the production of goods and services in capitalism is regulated by the profit motive rather than the fulfilment of human needs and requirements; the latter could conceivably be met through alternative (including non-capitalist) social and economic forms (LEYSHON, LEE and WILLIAMS, 2003). If new forms of capitalism (i.e., new economy firms) could function and operate without having to worry about social and physical investments and the social conditions of reproduction of labour power, then they would certainly do so. Yet in many of our examples, it is business interests (and their political allies) which have taken up the social (collective) provision cause with zeal and they have found willing partners in certain state agencies, environmental organisations, community groups and different sectors dealing with labour's reproduction, indeed in some cases with labour itself. The result has often been what we have identified as a new territorial politics of collective provision.

In our future work on NES in the U.S.A., Europe and Asia, we will be investigating in further depth the new territorial politics of collective provision. In the meantime, there are two remaining issues to consider. First, there is the issue of how matters relating to the politics of collective provision have been relatively neglected in the urban and regional development literature. It could be that struggles around the state for collective provision have been increasingly displaced away from demands on economic development and production, but this in turn only intensifies the fiscal crisis of the (local) state (PIVEN and FRIEDLAND, 1984). This begs the question as to 
how the collective provision needs of NES are met in the longer term without exposing local and regional state institutions and actors to a crisis of democratic legitimacy.

Second, there is the need to address the question: how new is the territorial politics of collective provision? It is insufficient simply to report a structural neglect of collective consumption as a particular feature of contemporary approaches to neoliberal urban growth regimes (COCHRANE, 1999). In fact, our research suggests that contemporary discourses of social inclusion and environmental sustainability have come much more into play in the politics of urban and regional development, whereas national government policy in countries like the U.S. and U.K. continues to emphasise fiscal conservatism and anticipate business (and voter) opposition to significant tax increases. In this context, recent attempts to represent NES as sustaining a particular "quality of life" for the creative class or responding voluntarily to national and global challenges of environmental and social sustainability need to be treated with a great deal of caution. By looking more closely at the new collective-provision demands of NES, there lies an opportunity to rethink conventional approaches to economic development, not least that have focussed relentlessly upon supply-side territorial policies to the exclusion of demand-side considerations. 


\section{References}

AGLIETTA M. (1979) A Theory of Capitalist Regulation. London, New Left Books.

ALLEN J. and COCHRANE A. (2007) Beyond the territorial fix: regional assemblages, politics and power Regional Studies 41, 1161-1176.

AMIN A. (Ed) (1994) Post-Fordism: A Reader. Blackwell, Oxford.

ATKINSON R. and CORREA D. (2007) The 2007 State New Economy Index: Benchmarking Economic Competition in the States. Washington DC, The Information and Technology Foundation, February. [Available to download on http://www.kauffman.org/items.cfm?itemID=766 (Ewing Marion Kauffman Foundation).]

BALASUBRAMANYAN V. and BALASUBRAMANYAN A. (2000) The software cluster in Bangalore, in J. H. DUNNING (Ed) Regions, Globalization and the Knowledge-Based Economy, pp. 349-363. Oxford University Press, Oxford.

BISH R.L. 1971 The Public Economy of Metropolitan Areas. Markham Series in Public Policy Analysis, Chicago.

BUNNELL T. (2002) Multimedia utopia? A geographical critique of high-tech development in Malaysia’s Multimedia Super Corridor Antipode 34, 265295.

CANIËLS M. and ROMIJN H. (2003) Dynamic clusters in developing countries: collective efficiency and beyond, Oxford Development Studies 31, 275292.

CASTELLS M. (1977) The Urban Question. MIT Press, Cambridge MA.

CASTELLS M. and HALL P. (1994) Technopoles of the World: The Making of $21^{\text {st }}$ Industrial Complexes. London, Routledge. 
CLARKE S. and GAILE G.L. (1989) Moving towards entrepreneurial state and local development strategies Policy Studies Journal 17, 574-598.

CLARKE S. and GAILE G.L. (1998) The Work of Cities. Minneapolis, MN, The University of Minnesota Press.

COCHRANE A. (1999) Redefining urban politics for the twenty-first century, in A.E.G. JONAS and D. WILSON (Eds) The Urban Growth Machine: Critical Perspectives Two Decades Later, pp. 109-124. SUNY Press, Albany, NY.

COURCHESNE C. (2004) What regional agenda?: Reconciling Massachusetts’s affordable housing law and environmental protection, Harvard Environmental Law Review 28, 215-247.

COX K.R. (1993) The local and the global in the New Urban Politics: A critical view. Environment and Planning D: Society and Space 11, 433-48.

COX K.R. (1999) The growth machine and ideologies of community, in A.E.G. JONAS and D. WILSON (Eds) The Urban Growth Machine: Critical Perspectives Two Decades Later, pp. 21-36. SUNY Press, Albany, NY.

COX K.R. (2002) Political Geography: Territory, State and Society. Blackwell. Oxford.

COX K.R. and JONAS A.E.G. (1993) Urban development, collective consumption, and the politics of metropolitan fragmentation Political Geography 12, 8-37.

COX K.R. and MAIR A.J. (1988) Locality and community in the politics of local economic development Annals of the Association of American Geographers 78, 307-325.

COX K.R. and MAIR A.J. (1991) From localised social structures to localities as agents Environment and Planning A 23, 197-213. 
CRANG P. and MARTIN R.L. (1991) Mrs Thatcher's vision of the 'new Britain' and the other sides of the ‘Cambridge phenomenon’ Environment and Planning D: Society and Space 9, 91-116.

EISINGER P. (1988) The Rise of the Entrepreneurial State Madison, WI, University of Wisconsin Press.

FLOOD J. and KABLACK M.A. (2008) Affordable housing recap and forecast, Massbuilder First Quarter, 22.

FLORIDA R. (2002) The Rise of the Creative Class New York, Basic Books.

GRAHAM S. and MARVIN S. (2001) Splintering Urbanism London, Routledge.

GRAY M., GOLOB E. and MARKUSEN A. (1996) Big firms, long arms, wide shoulders: the hub-and-spoke industrial district in the Seattle region Regional Studies 30, 551-666.

GCP (GREATER CAMBRIDGE PARTNERSHIP) (2001) Investing in Success: Action Plan Cambridge, GCP.

HARRISON B. (1992) Industrial districts - old wine in new bottles. Regional Studies 26, 469-483.

HARRISON J. (2007) From competitive regions to competitive city-regions: a new orthodoxy, but some old mistakes Journal of Economic Geography 7, 311332.

HACKLER D. (2003) High-tech location in five metropolitan areas Journal of Urban Affairs 25, 625-640.

HARVEY D .W. (1982) The Limits to Capital Oxford, Blackwell.

HARVEY D.W. (1985) The Urbanization of Capital Baltimore, Johns Hopkins Press.

HENDERSON J. (2004) The politics of mobility and business elites in Atlanta, Georgia Urban Geography 25, 193-216. 
HESS M. and YEUNG H.W-C. (2006) Whither global production networks in economic geography? Environment and Planning A 38, 1193-1204.

HORAN C. and JONAS A.E.G. (1998) Governing Massachusetts: uneven development and politics in metropolitan Boston Economic Geography (Special issue for the Annual Meeting of the Association of American Geographers), 83-95.

JAMES A. (2007) Everyday effects, practices and causal mechanisms of 'cultural embeddedness’: learning from Utah’s high tech regional economy Geoforum 38, 393-413.

JARVIS H. (2007) Home truths about care-less competitiveness International Journal of Urban and Regional Research 31, 207-214.

JONAS A.E.G. (1992) Corporate takeover and the politics of community: the case of Norton Company in Worcester Economic Geography 68, 348-372.

JONAS A.E.G. (1996a) Local labour control regimes: uneven development and the social regulation of production Regional Studies 30, 323-338

JONAS A.E.G. (1996b) In search of order: traditional business reformism and the crisis of neoliberalism in Massachusetts Transactions of the Institute of British Geographers 21, 617-634.

JONAS A.E.G. (2006) Pro scale: further reflections on the scale debate in human geography Transactions of the Institute of British Geographers 31, 399-406.

JONAS A.E.G. and PINCETL S. (2006) Rescaling regions in the state: the New Regionalism in California Political Geography 25, 482-505.

JONAS A.E.G. and WARD K. (2002) A world of regionalisms? Towards a US-UK urban and regional policy framework comparison Journal of Urban Affairs 24, $377-401$. 
KRUEGER R. and GIBBS D. (forthcoming) ‘Third Wave’ sustainability? Smart growth and regional development in the U.S. Regional Studies.

LAWTON-SMITH H. (2004) The financing of innovation: institutional support for high tech industry in Oxfordshire, in A. WOOD and D. VALLER (eds) Governing Local and Regional Economies: Institutions, Politics and Economic Development, pp.121-146. Aldershot, Ashgate.

LEIBOVITZ J. (2003) Institutional barriers to associative city-region governance: the politics of institution-building and economic governance in 'Canada's Technology Triangle' Urban Studies 40, 2613-2642

LEYSHON A., LEE R. and WILLIAMS C. (Eds) (2003) Alternative Economic Spaces Sage, London.

LIDDLE R. (2006) A common social justice policy for Europe, in A. GIDDENS, P. DIAMOND and R. LIDDLE (eds) Global Europe, Social Europe, pp. 279298. Cambridge, Polity.

LOGAN J.R. and MOLOTCH H.L. (1987) Urban Fortunes: The Political Economy of Place University of California Press, Berkeley.

LOVERING J. (1999) Theory led by policy? The inadequacies of the 'new regionalism' in economic geography illustrated from the case of Wales International Journal of Urban and Regional Research 23, 379-395.

MACLEOD, G. (2001) The new regionalism reconsidered: globalization, regulation and the recasting of political economic space” International Journal of Urban and Regional Research 25, 804-829.

MALECKI E. (2004) Jockeying for position: what it means and why it matters to regional development policy when places compete, Regional Studies 38, 11011120. 
MASSEY D., QUINTAS P. and WIELD D. (1992) High-tech Fantasies: Science

Parks in Society, Science and Space. Routledge, London.

McCANN E.J. (2007) Inequality and politics in the creative city-region: questions of liveability and state strategy International Journal of Urban and Regional Research 31, 188-196.

MORGAN K. (1997) The learning region: institutions, innovation and region renewal Regional Studies 31, 491-503.

MORGAN K. (2007) The polycentric state: new spaces of empowerment and engagement? Regional Studies 41, 1237-1252.

MORGAN K. and SAYER A. (1988) Microcircuits of Capital. Cambridge, Polity.

NEVAREZ L. (2003) New Money/Nice Town: How Capital Works in The New Urban Economy. Routledge, New York.

ODPM (Office of the Deputy Prime Minister) (2003) Sustainable Communities Building for the Future. ODPM, London.

PACEC (Public and Corporate Economic Consultants) (2003) The Cambridge Phenomenon: Fulfilling the Potential (on behalf of Greater Cambridge Partnership, Cambridgeshire County Council and East of England Development Agency). PACEC, Cambridge.

PECK J. and TICKELL A. (1995) The social regulation of uneven development: 'regulatory deficit', England's South East and the collapse of Thatcherism Environment and Planning A 27, 15-40

PECK J. and TICKELL A. (2002) Neoliberalizing space Antipode 34, 380-404

PATIBANDLA M. and PETERSON B. (2002) Role of transnational corporations in the evolution of a high-tech industry: the case of India's software industry, World Development 30, 1561-1577. 
PHILLIPS S.A.M. and YEUNG H.W-C. (2003) A place for R\&D? The Singapore Science Park Urban Studies 40, 707-732.

PIKE A., RODRÍGUEZ-POSE A. and TOMANAY J. (2006) Local and Regional Development. London, Routledge.

PIVEN F.F. and FRIEDLAND R. (1984) Public choice and private power: a theory of fiscal crisis, in A. KIRBY, P. KNOX and S. PINCH (Eds) Public Service Provision and Urban Development, pp.390-420. New York, Croom Helm/St. Martins.

RACO M. (2008) Key worker housing, welfare reform and the new spatial policy in England Regional Studies 42, 737-751.

SAXENIAN A. (1989) In search of power: the organization of business interests in Silicon Valley and Route 128 Economy and Society 18, 25-70.

SAXENIAN A. (1994) Regional Advantage: Culture and Competition in Silicon Valley and Route 128. Harvard University Press, Cambridge, MA.

SCOTT A.J. (1988) Flexible production systems and regional development: the rise of new industrial spaces in North America and Western Europe International Journal of Urban and Regional Research 12, 171-186.

SCOTT A.J. (2001) Global City-Regions: Trends, Theory, Policy. Oxford, Oxford University Press.

STABER U. (2007) Contextualising research on social capital in regional clusters International Journal of Urban and Regional Research 31, 505-521.

TIEBOUT C.M. (1955) A pure theory of local expenditures Journal of Political Economy 64, 416-424

WHILE A., JONAS A.E.G. and GIBBS D. (2004a) Unblocking the city: 
growth pressures, collective provision and the search for new spaces of governance in Greater Cambridge, England Environment and Planning A 36, 279-304.

WHILE A., JONAS A.E.G and GIBBS D. (2004b) The environment and the entrepreneurial city: the 'sustainability fix' in Manchester and Leeds International Journal of Urban and Regional Research 28, 549-569

WARD K. and JONAS A.E.G. (2004) Competitive city regionalism as a politics of space: a critical reinterpretation of the New Regionalism Environment and Planning A 36, 2119-2139.

WOOD A. and Valler D. (2004) Governing local and regional economies, in A. WOOD and D. VALLER (eds) Governing Local and Regional Economies: Institutions, Politics and Economic Development, pp.1-21. Aldershot, Ashgate.

YU P.D. (2003) Focus on high tech Regional Review 14, 6-9. 


\section{ENDNOTES}

${ }^{1}$ Although many readers will be familiar with terms like "new industrial spaces” and “clusters", we prefer to use the term "new economic spaces”. This is because we are interested not so much in industrial agglomeration or clustering per se as in the demands for infrastructure and services associated with developing and sustaining particular NES.

${ }^{2}$ In our previous research, we have examined new forms of urban and regional development in terms of the territorial politics of environmental and social sustainability (WHILE, JONAS and GIBBS, 2004a; 2004b).

${ }^{3}$ For the purposes of this paper, we use the term State when referring to the Commonwealth Government of Massachusetts. Below the State level, there is no unitary or single government authority for the Boston city-region. Instead the region is fragmented into numerous local municipalities operating under a system of local home rule. Metropolitan planning authorities and regional business organisations have been set up to deliver planning, infrastructure and housing on a regional and quasicooperative basis. KRUEGER and GIBBS (forthcoming) describe in some detail the increasingly important role of these metropolitan institutions in promoting more environmentally sustainable forms of development across the Boston city-region. ${ }^{4}$ See http://www.arc-of-innovation.org/, first accessed August 2007. The Boston cityregion has a rich and well-developed institutional landscape devoted to economic governance, albeit there are ongoing tensions amongst the different business interest groups and factions representing high tech industry, on the one hand, and manufacturing and services, on the other (JONAS, 1996b). The 495/MetroWest Corridor Partnership was set up to represent the interests of new economy firms, 
which were not being met effectively through existing local arrangements including local chambers of commerce and local jurisdictions. It was felt that more of a regional approach was required to address growth-induced infrastructural, planning and housing needs of local employers, both small and large (Interview with regional economic development practitioner, September, 2007).

${ }^{5}$ For a number of years, Chapter 40B has been a particular focus of struggle in the politics of growth State-wide in Massachusetts (see COURCHESNE, 2004, for a fuller discussion of this law).

${ }^{6}$ The viewpoint of I-495 house-builders is nicely illustrated by FLOOD and KABLACK (2008: 22): "Neighborhoods restrict the growth of new apartments or prevent subdivisions, which causes the demand for housing to disperse over larger areas (sprawl), and drives housing and commuting prices higher...This trend is very evident within the Route 495 area..., where there is virtually no undeveloped multifamily zoned land available outside of cities”. An attempt to repeal Chapter 40B in December 2007 failed to garner sufficient signatures to appear on a State-wide ballot measure.

${ }^{7}$ For example, a new partnership has emerged in Cambridgeshire to address the infrastructure deficit. Cambridgeshire Horizons developed out of the former Cambridgeshire Infrastructure Partnership. It is responsible for delivering some 47,500 new homes and £2.2bn of support infrastructure in the Cambridge sub-region by 2016, using the Cambridgeshire Structure Plan as a strategic framework and drawing into funds available for housing and community provision from the Labour government’s Sustainable Communities programme (see http://www.cambridgeshirehorizons.co.uk, first accessed March, 2005). 


\section{${ }^{8}$ Similar sorts of concerns underpinned older industrial centres in the nineteenth century. For example, COX (2002: 270-2) comments on how the "social imperialism" promoted by British Prime Minister Joseph Chamberlain sought to protect Birmingham based manufacturers from international competition. This policy conflicted with trade liberalisation favoured by London-based companies. ${ }^{9}$ Unreconstructed supporters of neo-liberal supply-side solutions might argue that demand has been met by the deregulation of monetary policy and freeing interest rates} from state control by allowing the Committee on Monetary Policy at the Bank of England to set them. This was a pet policy of Gordon Brown, the former U.K. Chancellor and now Prime Minister. Yet as "key workers" and other consumers of housing in NES like Cambridge become overleveraged with mortgage debt and interest rates rise, or as younger entrants to the labour market are unable to afford homes, this would present a national electoral problem for the Labour Government and for Gordon Brown. The politics of collective provision would hit back in national elections (cf. PECK and TICKELL, 1995, on Thatcherism and the South East, the UK's other "problem region”). Likewise in the U.S., the recent crisis in the sub-prime mortgage lending market has exposed weaknesses in the social regulation of financial firms that have profited from investing in metropolitan housing markets in the 1990s and early 2000s.

${ }^{10}$ In our wider research project, which is looking at the debates and coalitions forming around infrastructure and workforce housing in Boston, Seattle and Denver, there are emerging tensions between different sectors of the housing development industry, with growing pressure (from national developers and the regional business community) on local housing developers to invest in the "affordable" sector. This usually means building "workforce housing” around new transit development hubs 
located in both the central city and the suburbs. The national Urban Land Institute has been an important advocate of such policies in each of these cities. 